\title{
Cryptosporidium infections in birds - a review
}

\author{
Infecção por Cryptosporidium em aves - uma revisão \\ Alex Akira Nakamura ${ }^{1}$; Marcelo Vasconcelos Meireles ${ }^{1 *}$ \\ ${ }^{1}$ Faculdade de Medicina Veterinária, Universidade Estadual Paulista - UNESP, Campus de Araçatuba, Araçatuba, SP, Brasil
}

Received April 17, 2015

Accepted August 24, 2015

\begin{abstract}
Cryptosporidiosis is one of the main protozoan infections in birds. It manifests as either a respiratory or a digestive illness, and it affects a very large number of avian species across several continents. The aim of this review is to report on the main results of studies on cryptosporidiosis among birds and the importance of these results to veterinary medicine and public health.
\end{abstract}

Keywords: Cryptosporidium spp., wild birds, poultry.

\section{Resumo}

A criptosporidiose constitui-se em uma das principais infecçóes por protozoários em aves, manifestando-se como enfermidade respiratória ou digestiva, em dezenas de espécies aviárias, em vários continentes. O objetivo desse trabalho foi relatar, por meio de revisão de literatura, os principais resultados de estudos sobre criptosporidiose em aves e sua importância para a medicina veterinária e saúde pública.

Palavras-chave: Cryptosporidium spp., aves selvagens, aves domésticas.

\section{Introduction}

Protozoa of the genus Cryptosporidium parasitize fish, amphibians, reptiles, birds and mammals. Protozoan biological cycles take place on the surface of the epithelial cells in the gastrointestinal and respiratory tracts, in the bursa of Fabricius, and, less frequently, in other organs (CURRENT et al., 1986; BARTA \& THOMPSON, 2006; VALIGUROVÁ et al., 2008), causing clinical and subclinical infections (SANTÍN, 2013).

The first description of Cryptosporidium infection among birds was reported by Tyzzer (1929) and involved the cecal epithelium of chicken. Slavin (1955) described a new species of Cryptosporidium that was causing mortality among young turkeys and suggested the name Cryptosporidium meleagridis. Nearly two decades later, cryptosporidiosis was diagnosed among domestic geese (Anser anser) (PROCTOR \& KEMP, 1974) and broiler chickens (FLETCHER et al., 1975). Current et al. (1986) described the biological cycle of Cryptosporidium in domestic chickens and named the species Cryptosporidium baileyi. The third valid species of this parasite, Cryptosporidium galli, was described by Pavlásek (1999) from the proventriculi of chickens and was later revised by Ryan et al. (2003a).

Cryptosporidiosis is one of the main protozoan infections among birds. It manifests as either a respiratory or a digestive

*Corresponding author: Marcelo Vasconcelos Meireles. Faculdade de Medicina Veterinária, Universidade Estadual Paulista - UNESP, Rua Clóvis Pestana, 793, Bairro Dona Amélia, CEP 16050-680, Araçatuba, SP, Brasil. e-mail: marcelo@fmva.unesp.br disease, and it affects a very large number of avian species across all continents except Antarctica (Table 1). Various aspects of cryptosporidiosis among humans and animals have been addressed (RAMIREZ et al., 2004; XIAO et al., 2004; JEX et al., 2008; BOWMAN \& LUCIO-FORSTER, 2010; RYAN, 2010), but the literature regarding the occurrence of Cryptosporidium infection among avian species is demonstrably sparse.

The objective of the present study was to report on the main results of studies on cryptosporidiosis among birds and the importance of these results to veterinarian medicine and public health by reviewing the literature.

\section{Etiological Agent and Host Specificity}

Cryptosporidium spp. are parasites classified as members of the phylum Apicomplexa, class Sporozoea, subclass Coccidia, order Eucoccidiida and family Cryptosporidiidae, which contains a single genus, Cryptosporidium (FAYER, 2008). However, there is evidence that the genus Cryptosporidium might be more closely related to the Gregarinia than to the Coccidia (BARTA \& THOMPSON, 2006; CAVALIER-SMITH, 2014).

The classification of species within the genus Cryptosporidium is constantly being updated using molecular methods and data on morphology, biology and host specificity. There are descriptions of 27 to 30 different species of Cryptosporidium, although there is still 
Table 1. Cryptosporidium species and genotypes identified in birds using molecular diagnostic techniques.

\begin{tabular}{|c|c|c|c|c|c|}
\hline $\begin{array}{l}\text { Species/ } \\
\text { genotype }\end{array}$ & Host Order & $\begin{array}{c}\text { Site of } \\
\text { infection }\end{array}$ & Gene target & $\begin{array}{c}\text { Geographic } \\
\text { origin }\end{array}$ & Reference \\
\hline $\begin{array}{l}\text { Cryptosporidium } \\
\text { baileyi }\end{array}$ & $\begin{array}{c}\text { Anseriformes, Catharti- } \\
\text { formes, Charadriiformes, } \\
\text { Columbiformes, Falco- } \\
\text { niformes, Galliformes, } \\
\text { Gruiformes, Passeriformes, } \\
\text { Piciformes, Psittaciformes, } \\
\text { Strigiformes, Struthioni- } \\
\text { formes }\end{array}$ & $\begin{array}{l}\text { Bursa of Fabricius, } \\
\text { conjunctiva, } \\
\text { kidneys, respira- } \\
\text { tory tract, cloaca, } \\
\quad \text { rectum }\end{array}$ & $\begin{array}{l}18 S \text { rRNA, } \\
\text { Actin, } \\
\text { HSP-70, } \\
\text { COWP }\end{array}$ & $\begin{array}{l}\text { Africa, Asia, } \\
\text { Europe, North } \\
\text { America, South } \\
\text { America }\end{array}$ & $\begin{array}{l}\text { Morgan et al. (2001), Ryan et al. (2003b), } \\
\text { Chvala et al. (2006), Ng et al. (2006), Huber et al. } \\
\text { (2007), Van Zeeland et al. (2008), Nakamura et al. } \\
\text { (2009), Molina-López et al. (2010), Sevá et al. } \\
\text { (2011), Qi et al. (2011), Wang et al. (2011), } \\
\text { Coldwell et al. (2012), Schulze et al. (2012), } \\
\text { Wang et al. (2012), Baroudi et al. (2013), } \\
\text { Bougiouklis et al. (2013), Nakamura et al. (2014), } \\
\text { Qi et al. (2014), Wang et al. (2014b), Li et al. } \\
\text { (2015), Máca \& Pavlásek (2015) }\end{array}$ \\
\hline $\begin{array}{l}\text { Cryptosporidium } \\
\text { meleagridis }\end{array}$ & $\begin{array}{l}\text { Columbiformes, } \\
\text { Galliformes, Passeriformes, } \\
\text { Psittaciformes }\end{array}$ & $\begin{array}{l}\text { Small intestine, } \\
\text { large intestine }\end{array}$ & $\begin{array}{l}18 \mathrm{~S} \text { rRNA, } \\
\text { Actin, } \\
\text { HSP-70, } \\
\text { COWP, } \\
\text { GP60 }\end{array}$ & $\begin{array}{l}\text { Africa, Asia, } \\
\text { Europe, Oceania, } \\
\text { North America, } \\
\text { South America }\end{array}$ & $\begin{array}{l}\text { Morgan et al. (2000), Morgan et al. (2001), Ryan et al. } \\
\text { (2003b), Huber et al. (2007), Pagès-Manté et al. (2007), } \\
\text { Nakamura et al. (2009), Qi et al. (2011), Silverlås et al. } \\
\text { (2012), Wang et al. (2012), Baroudi et al. (2013), } \\
\text { Wang et al. (2014b), Li et al. (2015), Máca \& Pavlásek } \\
\text { (2015), Reboredo-Fernández et al. (2015) }\end{array}$ \\
\hline $\begin{array}{l}\text { Cryptosporidium } \\
\text { galli }\end{array}$ & $\begin{array}{l}\text { Bucerotiformes, } \\
\text { Galliformes, Passeriformes, } \\
\text { Psittaciformes, Phoenicop- } \\
\text { teriformes }\end{array}$ & Proventriculus & $\begin{array}{l}\text { 18S rRNA, } \\
\text { Actin, } \\
\text { HSP-70 }\end{array}$ & $\begin{array}{l}\text { Asia, Europe, } \\
\text { Oceania, South } \\
\text { America }\end{array}$ & $\begin{array}{l}\text { Ryan et al. (2003a), Ng et al. (2006), Antunes et al. } \\
\text { (2008), Nakamura et al. (2009), Silva et al. (2010), } \\
\text { Sevá et al. (2011), Qi et al. (2011), Nakamura et al. } \\
\text { (2014) }\end{array}$ \\
\hline Avian genotype I & Galliformes, Passeriformes & nd & $\begin{array}{l}\text { 18S rRNA, } \\
\text { Actin }\end{array}$ & $\begin{array}{l}\text { Oceania, South } \\
\text { America }\end{array}$ & Ng et al. (2006), Nakamura et al. (2009) \\
\hline Avian genotype II & $\begin{array}{l}\text { Galliformes, Psittaciformes, } \\
\text { Struthioniformes, }\end{array}$ & $\begin{array}{l}\text { Cloaca, rectum, } \\
\text { bursa of } \\
\text { Fabricius }\end{array}$ & $\begin{array}{l}18 S \text { rRNA, } \\
\text { Actin, } \\
\text { HSP-70 }\end{array}$ & $\begin{array}{l}\text { Asia, Oceania, } \\
\text { South America }\end{array}$ & $\begin{array}{l}\text { Santos et al. (2005), Meireles et al. (2006), Ng et al. } \\
\text { (2006), Nakamura et al. (2009), Sevá et al. (2011), } \\
\text { Nguyen et al. (2013), Wang et al. (2014b) }\end{array}$ \\
\hline Avian genotype III & $\begin{array}{l}\text { Passeriformes, } \\
\text { Psittaciformes, }\end{array}$ & Proventriculus & $\begin{array}{l}18 \mathrm{~S} \text { rRNA, } \\
\text { Actin, } \\
\text { HSP-70, } \\
\text { COWP }\end{array}$ & $\begin{array}{l}\text { Asia, Oceania, } \\
\text { North America, } \\
\text { South America }\end{array}$ & $\begin{array}{l}\text { Abe \& Makino (2010), Ng et al. (2006), } \\
\text { Nakamura et al. (2009), Makino et al. } \\
\text { (2010), Qi et al. (2011), Gomes et al. (2012), } \\
\text { Nakamura et al. (2014), Ravich et al. (2014) }\end{array}$ \\
\hline Avian genotype IV & Psittaciformes & nd & $18 \mathrm{~S}$ rRNA & Europe & $\mathrm{Ng}$ et al. (2006) \\
\hline Avian genotype V & Psittaciformes & nd & $\begin{array}{l}18 S \text { rRNA, } \\
\quad \text { actin, } \\
\text { HSP-70 }\end{array}$ & $\begin{array}{l}\text { Asia, South } \\
\text { America }\end{array}$ & $\begin{array}{c}\text { Abe \& Makino (2010), Qi et al. (2011), } \\
\text { Nakamura et al. (2014) }\end{array}$ \\
\hline $\begin{array}{l}\text { Goose genotypes } \\
\text { I-V }\end{array}$ & Anserifornes & nd & $18 \mathrm{~S}$ rRNA & North America & Jellison et al. (2004), Zhou et al. (2004) \\
\hline $\begin{array}{l}\text { Black duck geno- } \\
\text { type }\end{array}$ & Anseriformes & nd & $18 \mathrm{~S}$ rRNA & Oceania & Morgan et al. (2001) \\
\hline $\begin{array}{l}\text { Eurasian Wood- } \\
\text { cock genotype }\end{array}$ & Charadriiformes & Proventriculus & $\begin{array}{l}\text { 18S rRNA, } \\
\text { HSP-70 }\end{array}$ & Europe & Ryan et al. (2003b) \\
\hline $\begin{array}{l}\text { Cryptosporidium } \\
\text { andersoni }\end{array}$ & Galliformes & nd & $\begin{array}{l}\text { 18S rRNA, } \\
\text { Actin }\end{array}$ & Europe & $\mathrm{Ng}$ et al. (2006) \\
\hline $\begin{array}{l}\text { Cryptosporidium } \\
\text { muris }\end{array}$ & $\begin{array}{l}\text { Caprimulgiformes, } \\
\text { Struthioniformes }\end{array}$ & nd & $\begin{array}{l}18 \mathrm{~S} \text { rRNA, } \\
\text { HSP-70, } \\
\text { Actin }\end{array}$ & Asia, Europe & Ng et al. (2006), Qi et al. (2014) \\
\hline $\begin{array}{l}\text { Cryptosporidium } \\
\text { parvum }\end{array}$ & $\begin{array}{l}\text { Accipitriformes, } \\
\text { Anseriformes, Charadri- } \\
\text { iformes, Galliformes, } \\
\text { Passeriformes, Psittaciformes }\end{array}$ & $\begin{array}{l}\text { Small intestine, } \\
\text { caecum }\end{array}$ & $\begin{array}{l}\text { TRAP-C2, } \\
\text { beta- } \\
\text { tubulin, } 18 S \\
\text { rRNA, } \\
\text { COWP }\end{array}$ & $\begin{array}{l}\text { Asia, Europe, } \\
\text { North America, } \\
\text { South America }\end{array}$ & $\begin{array}{l}\text { Graczyk et al. (1998), Zhou et al. (2004), } \\
\text { Zylan et al. (2008), McEvoy \& Giddings (2009), } \\
\text { Nakamura et al. (2009), Gomes et al. (2012), } \\
\text { Reboredo-Fernández et al. (2015) }\end{array}$ \\
\hline $\begin{array}{l}\text { Cryptosporidium } \\
\text { hominis }\end{array}$ & Anseriformes & nd & $18 \mathrm{~S}$ rRNA & North America & Zhou et al. (2004) \\
\hline
\end{tabular}

nd: the site of infection was not reported. 
some debate regarding which species are valid (ŠLAPETA, 2013; RYAN \& HIJJAWI, 2015).

In birds, three species of Cryptosporidium have been reported, including C. baileyi, C. galli and C. meleagridis. Many genotypes have also been described, mainly based on molecular data (SMITH et al., 2007; XIAO \& FAYER, 2008; XIAO \& FENG, 2008; RYAN et al., 2014). The lack of biological, morphological or host specificity data has prevented the naming of new species related to Cryptosporidium avian genotypes (FAYER, 2010).

Cryptosporidium baileyi is the species most frequently diagnosed among birds, with reports of clinical or subclinical disease in 12 avian orders. Moreover, this is the most frequent species among the order Galliformes. Cryptosporidium galli has been found in several species of five different orders of birds, most frequently among Passeriformes and Psittaciformes, whereas C. meleagridis has been detected in four orders of birds, with infection occurring preferentially among the Galliformes (Table 1). Cryptosporidium meleagridis is the only avian species that infects mammals, and both natural and experimental infections have been reported (DARABUS, 1997; SRÉTER et al., 2000; AKIYOSHI et al., 2003; DARABUS \& OLARIU, 2003).

Avian genotypes I, II, III, IV and V have been reported in birds (SANTOS et al., 2005; MEIRELES et al., 2006; NG et al., 2006; ABE \& MAKINO, 2010), as have five goose genotypes (JELLISON et al., 2004; ZHOU et al., 2004), the black duck genotype and the Eurasian woodcock genotype (MORGAN et al., 2001) (Table 1).

There is still little information on the host specificity of the Cryptosporidium avian genotypes (Table 1). Avian genotype I has been found in canaries (Serinus canaria) and Indian peafowl (Pavo cristatus) (NG et al., 2006; NAKAMURA et al., 2009), whereas the presence of avian genotype III has been reported in several species of Psittaciformes and Passeriformes (NG et al., 2006; NAKAMURA et al., 2009; MAKINO et al., 2010; QI et al., 2011; GOMES et al., 2012; NAKAMURA et al., 2014).

The avian genotype II has been described in ostriches and in several Psittaciformes species (SANTOS et al., 2005; MEIRELES et al., 2006; NG et al., 2006; SEVÁ et al., 2011; NGUYEN et al., 2013). Although Wang et al. (2014b) reported the presence of avian genotype II in $0.78 \%(3 / 385)$ of fecal samples from chickens in China, Meireles et al. (2006) did not observe infection among chickens that were experimentally infected with avian genotype II and screened for Cryptosporidium infection using cytology, histology and oocyst screening in feces.

Infections by avian genotype IV and the Eurasian woodcock genotype have only been described once each: in the Japanese white-eye (Zosterops japonicus) and the Eurasian woodcock (Scolopax rusticola), respectively (NG et al., 2006). Regarding avian genotype $\mathrm{V}$, which was first described by Abe \& Makino (2010) among cockatiels (Nymphicus hollandicus), there have been two additional reports among birds of the order Psittaciformes (QI et al., 2011; NAKAMURA et al., 2014) and one report in reptiles (Iguana iguana) (KIK et al., 2011). The black duck genotype and the geese genotypes I to $\mathrm{V}$ have been described in the order Anseriformes and seem to have a narrower spectrum of hosts (JELLISON et al., 2004; ZHOU et al., 2004).
The infectivity of $C$. parvum to domestic chickens was assessed by Lindsay et al. (1987a) and Palkovič \& Maroušek (1989), who observed clinical signs after intratracheal inoculation with oocysts. However, parasite colonization was found to be restricted to the respiratory tract, and low numbers of oocysts were produced. Cryptosporidium species that are more common among mammals are sporadically found in birds, either in association with clinical signs, such as C.parvum in the stone curlew (Burbinus oedicnemus) (ZYLAN et al., 2008), or asymptomatically in birds, as reported by Qi et al. (2014) for ostriches with Cryptosporidium muris present in their feces.

\section{Epidemiological, Clinical and Pathological Aspects of Cryptosporidium spp. Infection in Birds}

Although many recently reported Cryptosporidium infections in the intestinal and respiratory tracts and the bursa of Fabricius in birds are related, respectively, to the presence of $C$. meleagridis and C. baileyi (RYAN, 2010), the possible roles of other species or genotypes of Cryptosporidium in the etiology of infections that were not characterized molecularly cannot be disregarded. For this reason, in the present review, the denomination Cryptosporidium sp. was used for cases where molecular characterization was not performed, unless the authors defined the species of Cryptosporidium, as in several studies regarding C. baileyi.

There are numerous descriptions of infection by Cryptosporidium among several avian species, particularly dating from the 1980 s and 1990 s, in which the diagnoses were accomplished only through cytological or histopathological observations without molecular characterization of the species or the genotype (GOODWIN, 1989; SRÉTER \& VARGA, 2000). The reported clinical signs were mostly related to the respiratory tract and the gastrointestinal tract and were sometimes associated with mortality. However, other tissues have been found to be colonized by Cryptosporidium sp. in clinical or subclinical infections: the bursa of Fabricius, ocular conjunctiva, middle ear, pancreas and kidneys (DHILLON et al., 1981; THAM et al., 1982; HOERR et al., 1986; MASON, 1986; RITTER et al., 1986; O'DONOGHUE et al., 1987; GOODWIN, 1988; NAKAMURA \& ABE, 1988; GOODWIN, 1989; GOODWIN \& BROWN, 1989; JARDINE \& VERWOERD, 1997; MURAKAMI et al., 2002; SRÉTER \& VARGA, 2000; RYAN, 2010).

The importance of cryptosporidiosis in commercial poultry production has not yet been determined because few studies on the influence of natural infection by Cryptosporidium spp. on the production parameters of these birds have been conducted. Snyder et al. (1988) investigated antibodies against Cryptosporidium spp. by means of the indirect ELISA technique among broiler chickens in the United States and observed that the flocks that presented the best performance were negative for Cryptosporidium. However, positive Cryptosporidium serology was not clearly correlated with poor performance. Other authors have reported positive correlations between the presence of $C$. baileyi infection in broiler chickens and decreased weight gain, greater 
incidence of airsacculitis, increased mortality and greater carcass condemnation rates in slaughterhouses (GORHAM et al., 1987; GOODWIN et al., 1996).

Infection by Cryptosporidium spp. in several species of wild and domestic birds has been demonstrated by many studies, with the reported prevalence values ranging from 0.8 to $44.4 \%$ (Table 2).

\section{Intestinal Infection by Cryptosporidium sp., C. meleagridis and C. parvum}

In turkeys, infection by $C$. meleagridis either presents subclinical characteristics (BERMUDEZ et al., 1988; WOODMANSEE et al., 1988) or has a clinical manifestation in the form of enteritis (SLAVIN, 1955; GOODWIN et al., 1988). In some cases, the infection is associated with other infectious agents (WAGES \& FICKEN, 1989). Clinical infection is characterized by decreased weight gain, diarrhea, small intestine distention by gas and mucus, and the presence of evolutionary stages of Cryptosporidium in the proximal and distal portions of the small intestine (GOODWIN et al., 1988; GHARAGOZLOU et al., 2006).

Although C. meleagridis infects domestic chickens (LINDSAY et al., 1989), clinical cryptosporidiosis related to intestinal infection occurs infrequently. Additionally, there are only occasional reports of intestinal cryptosporidiosis in domestic chickens, which is usually subclinical or associated with clinical signs in co-infections with other etiological agents (TYZZER, 1929; ITAKURA et al., 1984; GOODWIN, 1988; GOODWIN \& BROWN, 1989).

Infection by Cryptosporidium sp. has been correlated with the occurrence of enteritis and high mortality among quail, with the presence of diarrhea, small intestine containing clear aqueous fluid, cecum containing brown and foamy fluid, atrophy of the intestinal villi and presence of detached enterocytes in the intestinal lumen, as well as epithelial colonization by Cryptosporidium (HOERR et al., 1986). Cryptosporidium sp. in either natural infections (RITTER et al., 1986) or experimental infections (GUY et al., 1987), with or without associations with reoviruses, causes severe intestinal infection and high mortality among quail, in addition to presenting synergism with reoviruses.

One report described $C$. meleagridis infection in a breeding farm of red-legged partridges (Alectoris rufa) with clinical signs characterized by diarrhea and coughing, morbidity of $60-70 \%$ and mortality of $50 \%(100 / 200)$. On the same farm, during a later outbreak, mortality reached 89\% (400/450). Evolutionary stages of Cryptosporidium were present in the respiratory tracts and intestines of these birds. Because molecular characterization was only

Table 2. Worldwide prevalence of Cryptosporidium spp. in wild and domestic birds.

\begin{tabular}{|c|c|c|c|c|}
\hline Host species & $\begin{array}{c}\text { Geographic } \\
\text { origin }\end{array}$ & Species/genotype & $\begin{array}{l}\text { \% positive for Cryptosporidium } \\
\text { spp. (No. positive/No. sampled) }\end{array}$ & References \\
\hline Alectoris rufa & Czech Republic & C. baileyi, C. meleagridis & $22(145 / 663)$ & Máca \& Pavlásek (2015) \\
\hline Anas platyrhynchos & China & C. baileyi & $16.6(92 / 564)$ & Wang et al. (2010) \\
\hline \multirow{2}{*}{ Columba livia } & Iran & Cryptosporidium spp. & $2.94(3 / 102)$ & Radfar et al. (2012) \\
\hline & China & C. baileyi, C. meleagridis & $0.8(2 / 244)$ & Li et al. (2015) \\
\hline $\begin{array}{l}\text { Coturnix coturnix } \\
\text { japonica }\end{array}$ & & C. baileyi, C. meleagridis & $13.1(239 / 1818)$ & Wang et al. (2012) \\
\hline \multirow{3}{*}{$\begin{array}{l}\text { Ggllus gallus } \\
\text { domesticus }\end{array}$} & China & C. baileyi, C. meleagridis & $8.9(179 / 2015)$ & Wang et al. (2010) \\
\hline & Algeria & C. baileyi, C. meleagridis & $34.4(31 / 90)$ & Baroudi et al. (2013) \\
\hline & China & $\begin{array}{l}\text { Avian genotype II, C. baileyi, } \\
\text { C. meleagridis }\end{array}$ & $9.87(38 / 385)$ & Wang et al. (2014b) \\
\hline \multirow{3}{*}{ Meleagris gallopavo } & Iran & Cryptosporidium spp. & $35.3(17 / 60)$ & Gharagozlou et al. (2006) \\
\hline & USA & C. parvum & $6.3(5 / 79)$ & McEvoy \& Giddings (2009) \\
\hline & Algeria & C. meleagridis & $43.9(25 / 57)$ & Baroudi et al. (2013) \\
\hline \multirow{6}{*}{$\begin{array}{l}\text { Several } \\
\text { species }\end{array}$} & Australia & $\begin{array}{c}\text { Avian genotypes I, II, III, C. andersoni, } C \text {. } \\
\text { baileyi, C. galli, C. muris }\end{array}$ & $6.25(27 / 430)$ & Ng et al. (2006) \\
\hline & Brazil & $\begin{array}{l}\text { Avian genotypes I, II, III, C. baileyi, } \\
\text { C. galli, C. meleagridis, C. parvum }\end{array}$ & $4.86(47 / 966)$ & Nakamura et al. (2009) \\
\hline & China & $\begin{array}{c}\text { Avian genotypes I, II, III, V, C. baileyi, C. galli, } \\
\text { C. meleagridis, C. parvum }\end{array}$ & $8.1(35 / 434)$ & Qi et al. (2011) \\
\hline & Brazil & Avian genotype II, C. baileyi, C. galli & $6.6(16 / 242)$ & Sevá et al. (2011) \\
\hline & Nigeria & Cryptosporidium spp. & $7.4(66 / 890)$ & Bamaiyi et al. (2013) \\
\hline & Spain & C. meleagridis, C. parvum & $8.3(36 / 433)$ & $\begin{array}{l}\text { Reboredo-Fernández et al. } \\
\qquad(2015)\end{array}$ \\
\hline \multirow{4}{*}{ Struthio camelus } & Brazil & Cryptosporidium spp. & $44.4(50 / 77)$ & Oliveira et al. (2008) \\
\hline & China & C. baileyi & $11.7(53 / 452)$ & Wang et al. (2011) \\
\hline & Vietnam & Avian genotype II & $23.7(110 / 464)$ & Nguyen et al. (2013) \\
\hline & China & C. baileyi, C. muris & $10.2(31 / 303)$ & Qi et al. (2014) \\
\hline
\end{tabular}


performed on the intestinal content, from which $C$. meleagridis was identified, the authors of the study suggested that the respiratory infection could have been caused by $C$. meleagridis, although it was an unusual location, or could have been due to co-infection with C. baileyi (PAGÈS-MANTÉ et al., 2007).

Enteritis due to Cryptosporidium sp. has been reported among pigeons, with clinical signs such as diarrhea, hyperemia and intestinal distension and the presence of evolutionary stages of the parasite in the epithelium of the small intestine (ÖZKUL \& AYDIN, 1994).

The importance of the prevalence of intestinal infection among Psittaciformes has not been determined. However, intestinal cryptosporidiosis associated with clinical signs has been observed among budgerigars (Melopsittacus undulatus) (GOODWIN \& KRABILL, 1989), cockatiels (Nymphicus hollandicus) (GOODWIN \& KRABILL, 1989; LINDSAY et al., 1990), ring-necked parrots (Psittacula krameri) (MORGAN et al., 2000) and lovebirds, which exhibited a high mortality rate (Agapornis sp.) (BELTON \& POWELL, 1987).

Although infection by $C$. parvum is not common among birds, Zylan et al. (2008) described a case of catarrhal enteritis and mortality among stone curlews (Burhinus oedicnemus) in Saudi Arabia.

\section{Infection by Cryptosporidium sp., C. baileyi and Avian Genotype II in the Ocular Conjunctiva, Respiratory Tract, Bursa of Fabricius, Rectum and Cloaca}

Cryptosporidium sp. and C. baileyi are frequently regarded as etiological agents for infections in the upper respiratory system, middle ear and ocular conjunctiva of wild birds, such as owls (Otus scops), swallows (Petrochelidon pyrrhonota), falcons (Falco cherrug and Falco rusticolus X Falco cherrug) and red grouse (Lagopus lagopus scoticus) (VAN ZEELAND et al., 2008; MOLINA-LÓPEZ et al., 2010; COLDWELL et al., 2012; LEY et al., 2012; BOUGIOUKLIS et al., 2013; BAINES et al., 2014), and of domesticated birds, such as domestic chickens (BLAGBURN et al., 1991), geese (Anser anser f. domestica) (CHVALA et al., 2006), turkeys (GLISSON et al., 1984), ducks (MASON, 1986; O'DONOGHUE et al., 1987), peacocks (MASON \& HARTLEY, 1980) and pheasants (RANDALL, 1986).

Respiratory infection may be restricted to the upper respiratory tract, or it may disseminate to the lower respiratory tract, including the bronchia, lungs and air sacs (Figure $1 \mathrm{a}-\mathrm{c}$ ). This may occur with $C$. baileyi alone or in association with other etiological agents of respiratory infections in chickens, such as Escherichia coli (Figure 1d) and the infectious bronchitis virus, and can result in high mortality (GOODWIN, 1989; BLAGBURN et al., 1987; BLAGBURN et al., 1991; MEIRELES et al., 1999). Several reports have been published on infections by Cryptosporidium sp. in turkeys and quails, with or without associations with other etiological agents (THAM et al., 1982; TARWID et al., 1985; MURAKAMI et al., 2002).

Oral infection by $C$. baileyi is generally subclinical, although there may be decreased weight gain, which may only be transitory (BLAGBURN et al., 1987; LEVY et al., 1988; MEIRELES et al., 1998a). After oral or intratracheal infection, C. baileyi colonizes the bursa of Fabricius, which presents slight hyperemia and mucus on the mucosal surface. The exudation of products generated from the inflammation, especially heterophils, plasma and cell residues, results in the deposition of a caseous exudate in the lumen of the bursa of Fabricius (Figure 2a) (GUY et al., 1988; MEIRELES et al., 1998b).

Divergent reports exist on the effects of cryptosporidiosis on the immune system. Cryptosporidium baileyi causes a severe infection in the bursa of Fabricius (Figure 2b), which is the organ responsible for the humoral immune response in birds (SCOTT, 2004). Although experimental infections with $C$. baileyi have been found to present diffuse chronic superficial purulent bursitis with epithelial hyperplasia and hypertrophy (Figure 2c) and slight lymphoid atrophy (GUY et al., 1988; LEVY et al., 1988; GOODWIN \& BROWN, 1989; MEIRELES et al., 1998b), no influence on the humoral immune response of chickens has been observed (BLAGBURN et al., 1987; MEIRELES et al., 1998b; ABBASSI et al., 2000). Nevertheless, other reports have shown that $C$. baileyi infection had a suppressive effect on the humoral immune response of birds to the pathogenic virus or vaccine virus for Marek's disease (NACIRI et al., 1989), the Gumboro disease vaccine virus (LEVY et al., 1988), reoviruses (GUY et al., 1988), the Newcastle disease vaccine virus (RHEE et al., 1998a; ELADL et al., 2014), the infectious bronchitis vaccine virus (RHEE et al., 1998b), Brucella abortus (RHEE et al., 1998c) and the avian influenza vaccine virus (HAO et al., 2008; ELADL et al., 2014).

In addition to the possible immunosuppression caused by C. baileyi, even if only transitory, the association of C. baileyi with other infectious agents may result in high mortality and decreased weight gain among chickens. Among the agents that may present synergistically with $C$. baileyi are the virus vaccine (Rispens) for Marek's disease (ABBASSI et al., 2000), the avian infectious anemia virus (HORNOK et al., 1998), the Gumboro disease virus (LEVY et al., 1988) and reoviruses (GUY et al., 1988). In contrast, Meireles et al. (1995) did not observe any synergism among broiler chickens that were experimentally infected with Toxoplasma gondii and C. baileyi.

There have been reports that infection by Cryptosporidium sp. in ostriches resulted in prolapse of the phallus and cloaca (ALLWRIGHT \& WESSELS, 1993; BEZUIDENHOUT et al., 1993; PENRITH \& BURGER, 1993; PENRITH et al., 1994) and in pancreatic necrosis (JARDINE \& VERWOERD, 1997). The avian genotype II colonizes the epithelium of the cloaca (Figure $2 \mathrm{~d}$ ) and, less frequently, the rectum and bursa of Fabricius of ostriches. The nfection results in prolapse of the cloaca (Figure 3a), particularly if stressful conditions lead to immunosuppression or if there are poor husbandry practices relating to feed, water or hygiene (SANTOS et al., 2005).

\section{Infection in the Proventriculus by Cryptosporidium sp., Cryptosporidium galli, C. muris, Avian Genotype III and the Eurasian Woodcock Genotype}

Cryptosporidium galli infects several species of birds of the orders Bucerotiformes, Galliformes, Passeriformes, Phoenicopteriformes and Psittaciformes (Table 1). The pathogenicity of the gastric 


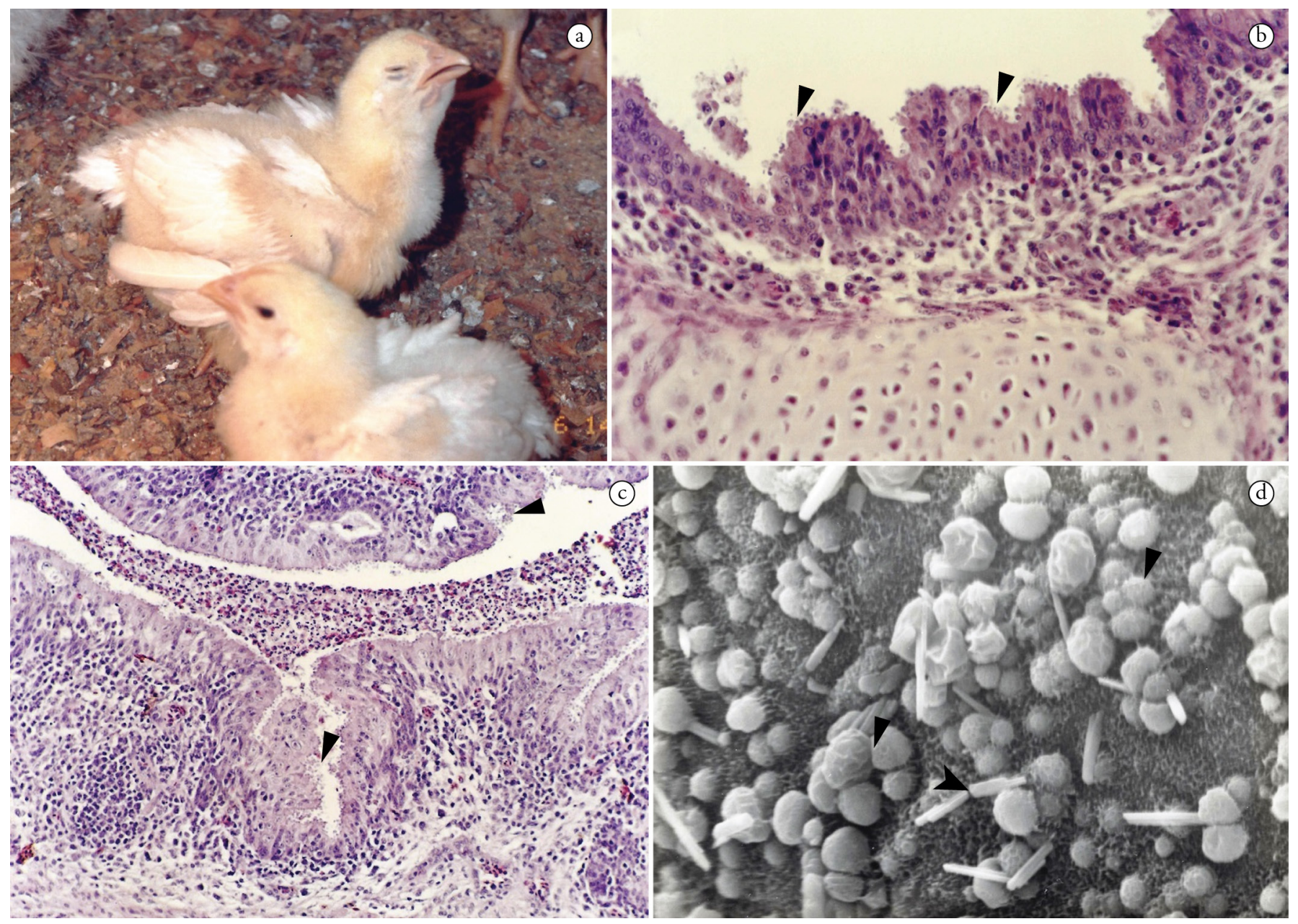

Figure 1. a: Chicken showing dyspnea after intratracheal inoculation of C. baileyi oocysts. b: Light micrograph of chicken trachea. Developmental stages of $C$. baileyi adhered to the epithelial surface (arrows), epithelial hyperplasia and infiltration of inflammatory cells in the submucosa (H\&E stain, 400x). c: Light micrograph of chicken lung tissue. Developmental stages of C. baileyi adhered to the bronchial epithelial surface (arrows), inflammatory cells infiltrating both submucosa and epithelium, and inflammatory exudate filling the bronchial lumen (H\&E stain, 200x). d: Scanning electron micrograph of chicken tracheal epithelium showing severe loss of cilia and concomitant infection with C. baileyi (arrow) and Escherichia coli (arrowhead) (2,000x).

species of Cryptosporidium has not yet been determined. Gastric infections by C. galli or Cryptosporidium sp. may be subclinical or associated with clinical signs characterized by apathy, diarrhea, weight loss, and sporadic mortality (BLAGBURN et al., 1990; CLUBB, 1997; MORGAN et al., 2001; ANTUNES et al., 2008; SILVA et al., 2010).

Infection with $C$. galli is characterized by intermittent and chronic shedding of oocysts in the feces. C. galli is able to infect young and adult birds and cause chronic gastric infection similar to $C$. serpentis in snakes (SILVA et al., 2010). Thus, Antunes et al. (2008) and Silva et al. (2010) suggested that infections by C. galli could be responsible for chronic proventriculitis in birds, which would predispose them to secondary infections by other pathogens.

The avian genotype III has also been found among several species of Passeriformes and Psittaciformes (Table 2). As with C. galli, avian genotype III causes chronic gastric disease, with clinical signs that include vomiting, weight loss and macroscopic and microscopic lesions in the proventriculus (MAKINO et al., 2010; RAVICH et al., 2014).

Cryptosporidium muris and C. andersoni infect several species of mammals and are occasionally related to clinical signs (SANTÍN, 2013). In birds, C. muris and C. andersoni oocysts may be present in fecal samples, possibly due to an actual infection or to being mechanically transported (NG et al., 2006). Subclinical infection by $C$. muris, which has apparently adapted to a new host, has been described among adult ostriches in China (QI et al., 2014).

There is only one report of infection in the proventriculus that was caused by the Eurasian woodcock genotype; this infection was described in the Czech Republic in a Eurasian woodcock (Scolopax rusticola) that died during the quarantine period (RYAN et al., 2003b). 

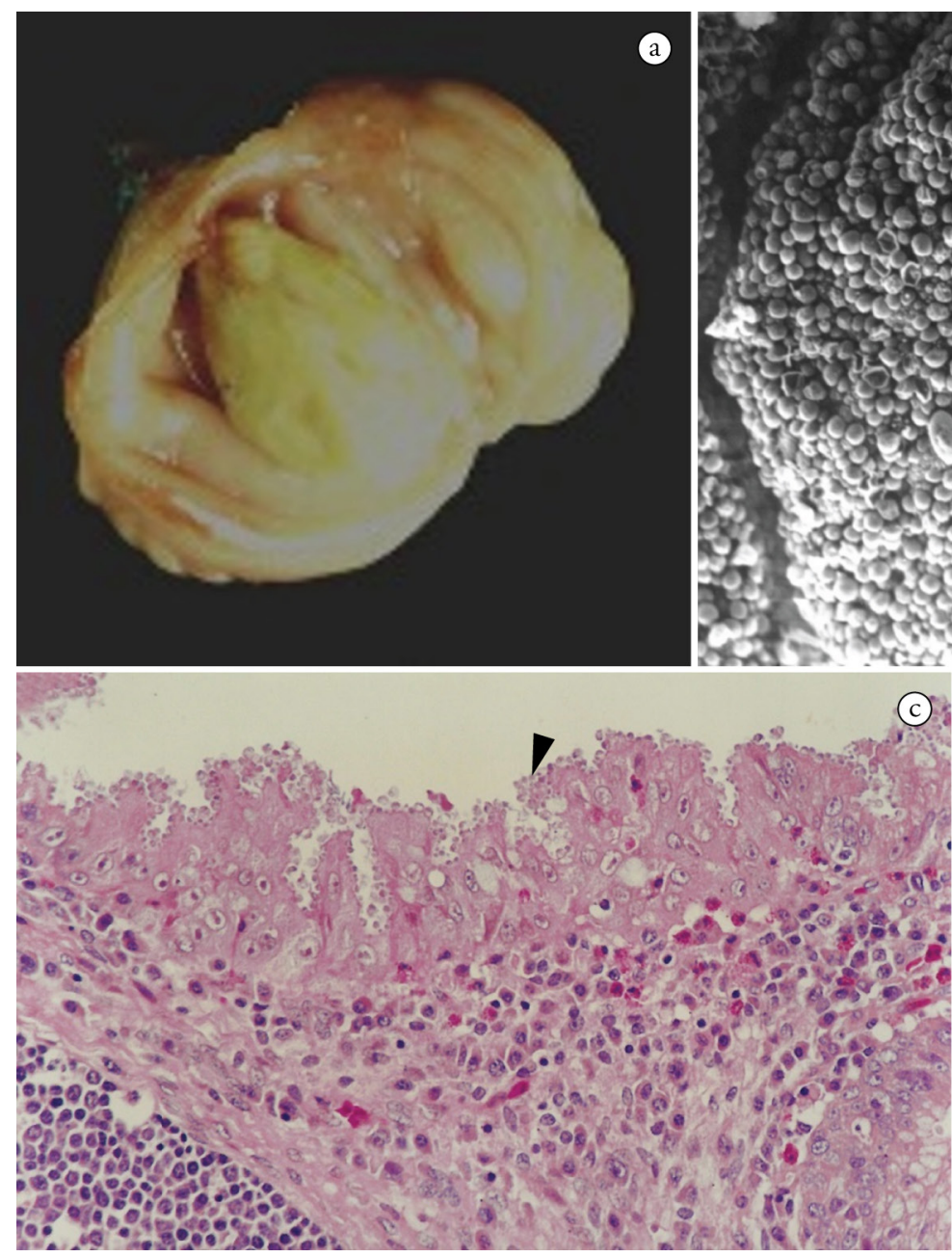

(c)
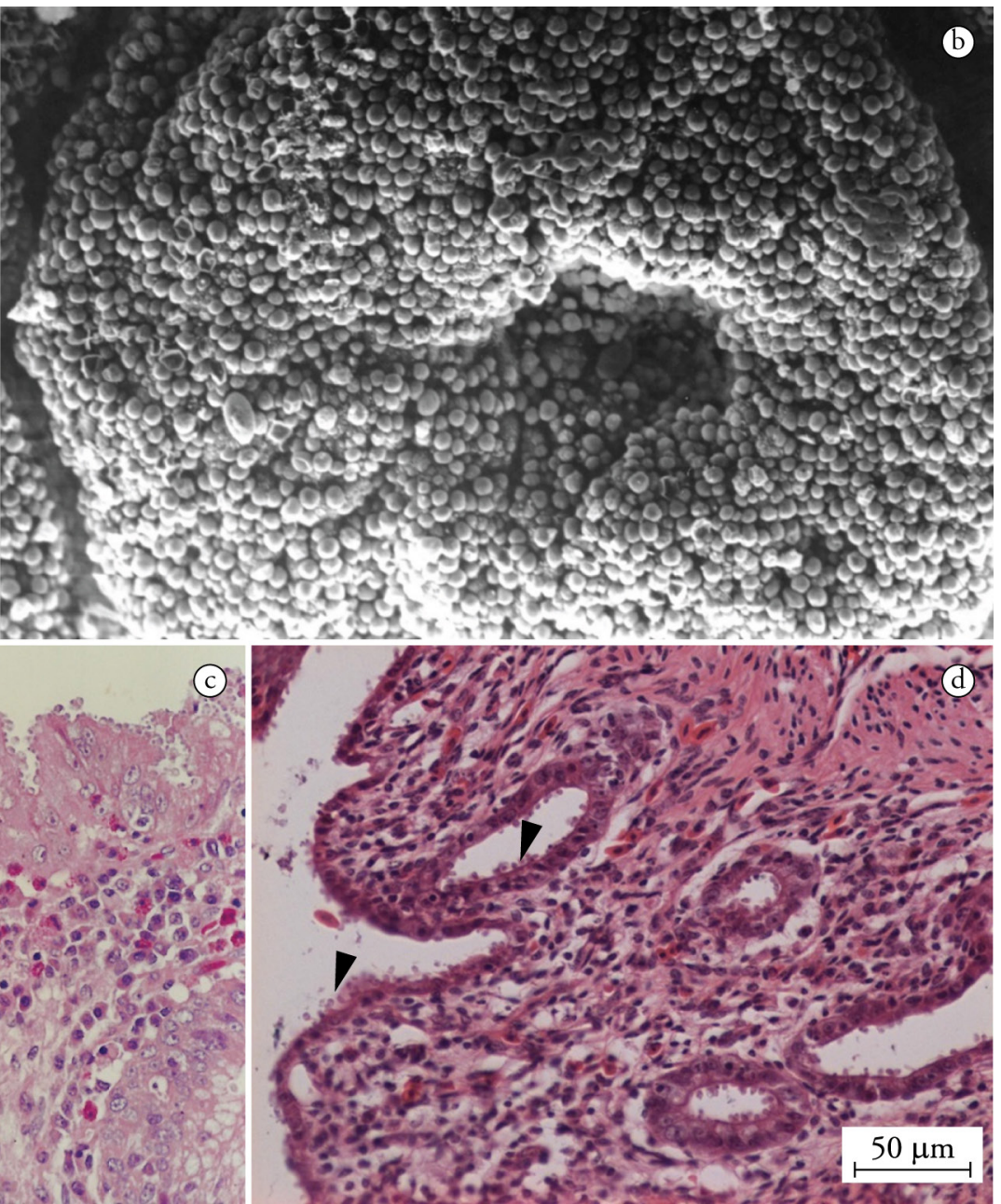

Figure 2. a: Caseous exudate filling the lumen of bursa of Fabricius of a chicken infected with C. baileyi. b: Scanning electron micrograph of bursa of Fabricius of a chicken infected with $C$. baileyi. Massive infection with parasite developmental stages covering the epithelial surface (700x). c: Light micrograph of chicken bursa of Fabricius. Developmental stages of $C$. baileyi adhered to the epithelial surface, epithelial hyperplasia and inflammatory cells infiltrating both submucosa and epithelium (H\&E stain, 400x). d: Light micrograph of ostrich urodeum. Developmental stages of Cryptosporidium avian genotype II adhered to the epithelial surface and inflammatory cell infiltration in the submucosa (H\&E stain, 400x).

\section{Infection by Other Avian Genotypes of Cryptosporidium}

Tissue tropism or the clinical importance of other genotypes of Cryptosporidium among birds has not been determined. Avian genotype I and avian genotype $\mathrm{V}$ show genetic similarity to $C$. baileyi and avian genotype II (ABE \& MAKINO, 2010; MEIRELES et al., 2006; NG et al., 2006). Because species with greater genetic similarity present similar tissue tropism, as observed with $C$. parvum and $C$. meleagridis, with $C$. baileyi and avian genotype II and with $C$. galli and avian genotype III (XIAO et al., 2004; NG et al., 2006), it is likely that avian genotype $\mathrm{I}$ and avian genotype $\mathrm{V}$ colonize the final portion of the intestine, cloaca, bursa of Fabricius or respiratory system, and avian genotype IV, the proventriculus.
The hosts of the other avian genotypes described to date are as follows: avian genotype I: the canary (Serinus canaria) (NG et al., 2006; NAKAMURA et al., 2009) and the Indian peafowl (Pavo cristatus) (NAKAMURA et al., 2009); avian genotype IV: the Japanese white-eye (Zosterops japonicus) (NG et al., 2006); and avian genotype $\mathrm{V}$ : the cockatiel (Nymphicus hollandicus) (ABE \& MAKINO, 2010; QI et al., 2011) and the blue-fronted parrot (Amazona aestiva) (NAKAMURA et al., 2014).

\section{Diagnosis of Cryptosporidiosis Among Birds}

Experience is a fundamental factor in diagnosing cryptosporidiosis because Cryptosporidium oocysts are small in comparison with other coccidians, do not present sporocysts, are difficult to 


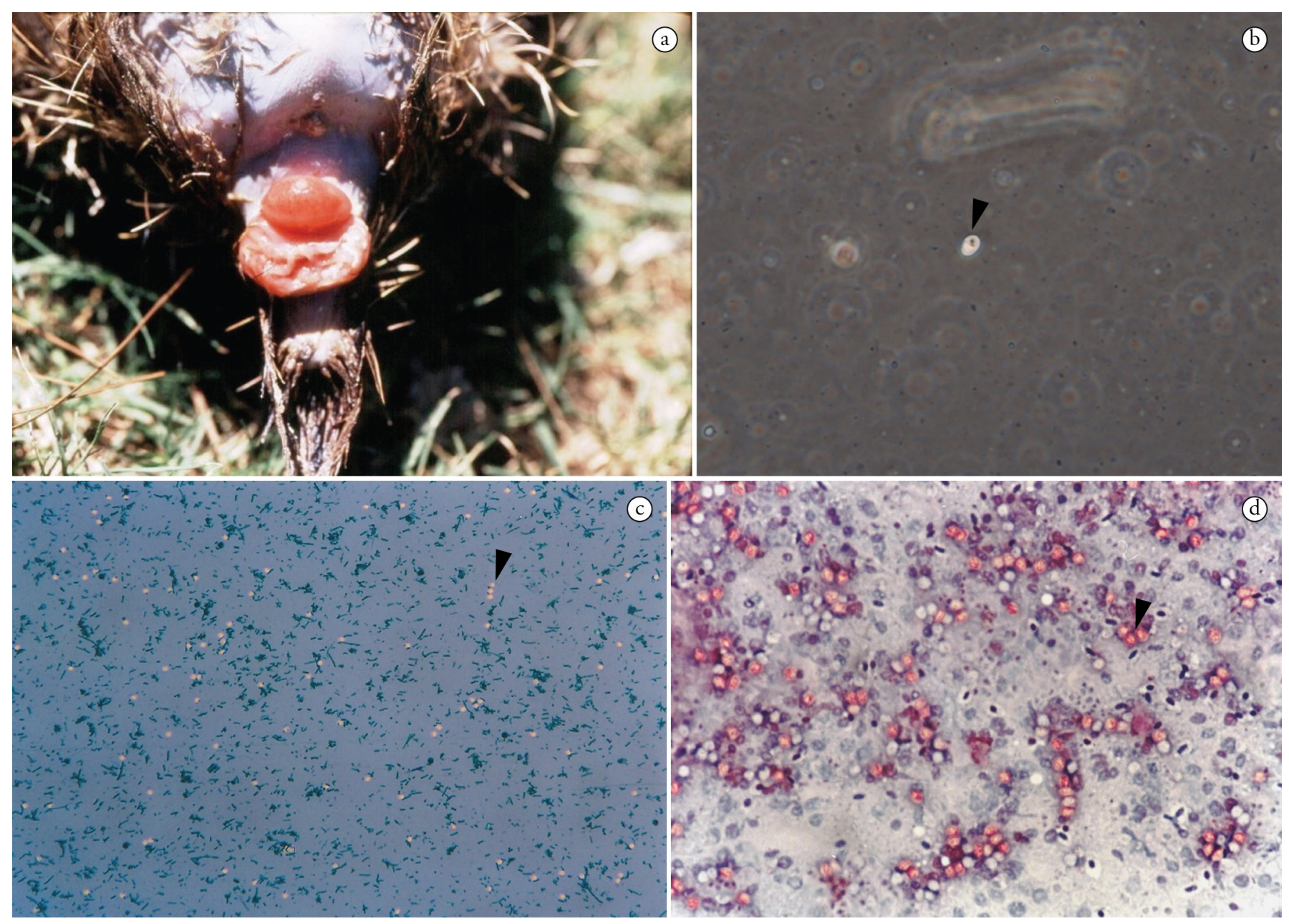

Figure 3. a: Cloacal prolapse in ostrich chick infected with Cryptosporidium avian genotype II. b: Single oocyst of $C$. galli (arrow). Fecal sample from a chronically infected adult canary processed using the Sheather's centrifugal flotation procedure (Phase contrast microcopy, 400x). c: Numerous oocysts of Cryptosporidium avian genotype II (arrow). Fecal sample from an ostrich chick processed using the ether centrifugal sedimentation procedure (Malachite green negative stain, 100x). d: Light micrograph of chicken bursa of Fabricius mucosal smear. Developmental stages of C. baileyi (arrow) (Safranin methylene blue stain, 200x).

observe, and are morphologically similar to fungi and yeast spores (CASEMORE, 1991). In samples with few oocysts in particular, care is needed to avoid false-positive results in fecal samples examined using the most common diagnostic methods, such as acid-fast staining or viewing oocysts under an optical microscope after concentration with saturated solutions of sugar, zinc sulfate or sodium chloride.

False-negative results are also common in samples with a low number of oocysts because of the low sensitivity of the staining techniques (JEX et al., 2008). In infections with C. galli, chronic shedding occurs, and few oocysts (Figure $3 \mathrm{~b}$ ) are observed per slide (ANTUNES et al., 2008). The amount of oocyst shedding and the patent period of infection with $C$. baileyi and $C$. meleagridis vary according to the age and species of the host (SRÉTER \& VARGA, 2000).

The diagnostic methods using microscopy that are most used and least expensive involve screening for oocysts after centrifugal flotation in Sheather's solution, followed by phase contrast microscopy (Figure 3b) or bright-field microscopy (CARDOZO et al., 2008; TEIXEIRA et al., 2011a) and any of the many staining techniques for fecal samples, including negative malachite green staining (Figure 3c) (ELLIOT et al., 1999) and acid-fast staining (HENRIKSEN \& POHLENZ, 1981; ORTOLANI, 2000; CARDOZO et al., 2008). In morphometric studies, morphological and morphometric alterations in oocysts should be considered when fecal smears are subjected to staining techniques (MEIRELES \& FIGUEIREDO, 1992; CARDOZO et al., 2005).

Several staining techniques are useful for screening of the evolutionary stages of Cryptosporidium in histological sections and in mucosal smears, including hematoxylin and eosin, safranin-methylene blue (Figure 3d) and acid-fast stains (Figure 4). Furthermore, Cryptosporidium DNA can be detected in tissue sections using fluorescent in situ hybridization (LATIMER et al., 1988; CHVALA et al., 2006; JEX et al., 2008). 


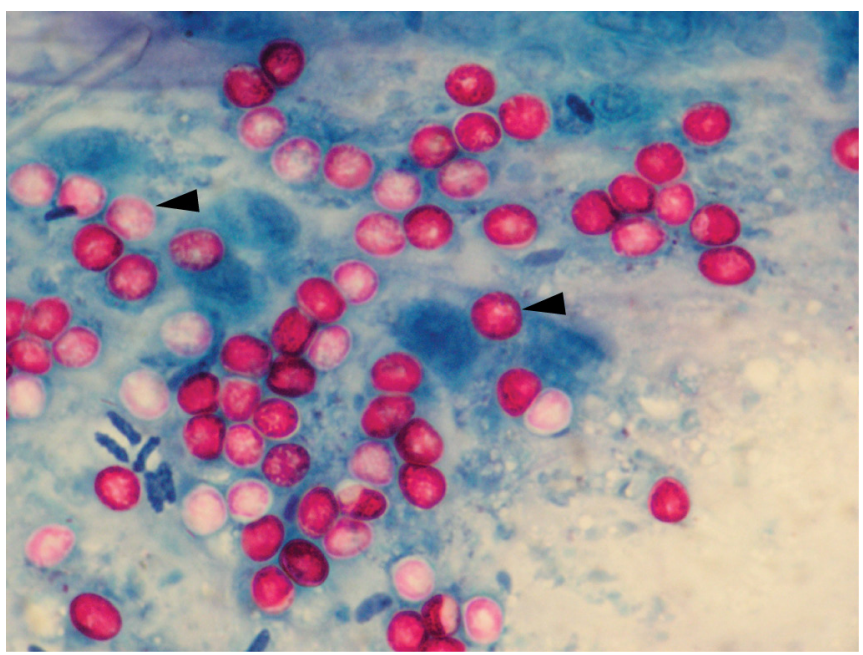

Figure 4. Light micrograph of lesser seed-finch proventriculus mucosal smear. Developmental stages of C. galli (arrows) (Kinyoun acid-fast stain, 1,000x).

Immunological methods for Cryptosporidium spp. diagnosis have been extensively reviewed (JEX et al., 2008; CHALMERS \& KATZER, 2013). The detection of Cryptosporidium by capture enzyme-linked immunoassays (ELISA) or direct fluorescent antibody (DFA) assays using commercially available antibodies have been extensively adopted in fecal and environmental samples; as a rule, they present higher sensitivity and higher specificity than oocyst-staining techniques.

The antigens targeted by capture ELISA and DFA present cross-reactivity among the different species of Cryptosporidium, and therefore, does not allow species-specific diagnosis (GRACZYK et al., 1996; JEX et al., 2008; CHALMERS et al., 2011; TEIXEIRA et al., 2011b). Although both methods are commonly applied to detect $C$. parvum antigens (JEX et al., 2008), they may be useful for the diagnosis of avian cryptosporidiosis (RICHTER et al., 1994; GRACZYK et al., 1996; ROHELA et al., 2005; PAGÈSMANTÉ et al., 2007).

Although the oocysts of some species present distinct morphology and morphometry, microscopic analysis does not allow species characterization because small variations exist in these parameters, and in many cases, the oocysts may be identical between different species or genotypes (RYAN, 2010). However, a presumptive diagnosis of gastric, intestinal or respiratory/bursal/cloacal cryptosporidiosis in birds can be accomplished by the presence of ellipsoidal oocysts measuring 7.5-8.5 × 6.0-6.4 $\mu \mathrm{m}$; spherical, irregularly spherical or slightly elongated oocysts measuring 4.5-6.0 $\times 4.2-5.3 \mu \mathrm{m}$; or ovoid oocysts measuring 6.0-7.5 $\times$ 4.8-5.7 $\mu \mathrm{m}$, respectively (CURRENT et al., 1986; LINDSAY et al., 1989; RYAN, 2010).

Molecular characterization of Cryptosporidium is performed by means of PCR, followed by either restriction fragment length polymorphism (RFLP) or sequencing of the amplified fragments. The gene most used for determining the species or genotype is $18 \mathrm{~S}$ rRNA (RYAN et al., 2014). In comparison with the species of Cryptosporidium found in mammals, few sequences for the Cryptosporidium of avian species have been published in
GenBank. When better resolution is needed to identify genetically similar species or genotypes, the relevant sequences of avian Cryptosporidium that are available relate to actin gene, heat shock protein gene (HSP-70) and Cryptosporidium oocyst wall protein gene (COWP) (Table 1). The 60-kDa glycoprotein (GP60) gene is used for subtyping C. meleagridis in molecular epidemiology studies (STENSVOLD et al., 2014; WANG et al., 2014a).

The genetic similarity between avian genotype II and avian genotype $\mathrm{V}$ in the $18 \mathrm{~S} \mathrm{rRNA}$ gene is $99.9 \%$. Only a substitution of $\mathrm{G}$ by $A$ in positions 329 and 378 differentiates the sequences of avian genotype II (DQ290031) and avian genotype V (AB471646), respectively. Because of this genetic similarity and the possibility of intraspecies variations in the 18S rRNA gene, classification of these two avian genotypes is recommended only after at least one gene that presents greater interspecies polymorphism, such as the HSP-70 gene or the actin gene (ABE \& MAKINO, 2010; NG et al., 2006; MEIRELES et al., 2006), has been analyzed.

Species-specific diagnosis using molecular biology techniques is also possible. Recently, Nakamura et al. (2014) developed a real-time PCR specifically for diagnosing C. galli and avian genotype III.

\section{Treatment and Prophylaxis}

Many drugs have been tested for the treatment of cryptosporidiosis, but the US Food and Drug Administration (FDA) has approved only nitazoxanide for use in humans (SMITH \& CORCORAN, 2004; STRIEPEN, 2013). Although halofuginone has shown variable efficacy, an effective drug for the prophylaxis and treatment of animal cryptosporidiosis is still lacking (LINDSAY et al., 1987b; SRÉTER et al., 2000; SHAHIDUZZAMAN \& DAUGSCHIES, 2012).

Cryptosporidium oocysts are resistant to environmental stress and to the disinfectants commonly used in avian facilities. The prevention and control of avian cryptosporidiosis must rely on rigorous measures related to nutritional and sanitary management to prevent exposure to oocysts and the prophylaxis of concomitant diseases that are commonly associated with avian cryptosporidiosis (SANTOS et al., 2005; SRÉTER \& VARGA, 2000; SILVA et al., 2010; SHAHIDUZZAMAN \& DAUGSCHIES, 2012).

\section{Importance for Public Health}

More than $90 \%$ of human Cryptosporidium infections are related to $C$. hominis or $C$. parvum, although there are sporadic reports of infections with other Cryptosporidium species or genotypes. Among the Cryptosporidium species and genotypes of avian hosts, only C. meleagridis has a wider host spectrum and is able to infect humans; in fact, it is the third most common cause of human cryptosporidiosis. In some countries, such as Peru and Thailand, C. meleagridis is responsible for $10-20 \%$ of human Cryptosporidium infections, with a frequency similar to that of infection by C. parvum (XIAO \& FENG, 2008; CHALMERS \& GILES, 2010; ELWIN et al., 2012; INSULANDER et al., 2013).

Silverlås et al. (2012) reported the possible zoonotic transmission of $C$. meleagridis in Sweden when samples with identical nucleotide 
sequences for the 18S rRNA and HSP-70 genes were found in hens, broiler chickens and an infected person. Further studies using phylogenetic analysis of multiple loci have suggested that the $C$. meleagridis found in birds may be related to isolates from humans and that birds may constitute an infectious source of human infections by $C$. meleagridis (STENSVOLD et al., 2014; WANG et al., 2014a).

Epidemiological studies have reported the presence of $C$. meleagridis in domestic birds and environmental samples. In Algeria, a report showed a high prevalence of $C$. meleagridis: $34 \%(26 / 90)$ in chickens and 44\% (25/57) in turkeys (BAROUDI et al., 2013). However, in China, a low prevalence was described for $C$. meleagridis among broiler chickens $(0.52 \% ; 2 / 385)$ (WANG et al., 2014b), laying hens $(0.19 \%$; 3/1542) (WANG et al., 2010) and quails $(0.22 \%$; 4/1818) (WANG et al., 2012). Li et al. (2012) found C. meleagridis in $24.4 \%(22 / 90)$ of the wastewater samples collected from four cities in China.

The oocysts of $C$. parvum are sporadically present in fecal samples of asymptomatic birds that are kept either as pets or in zoos. In most situations, the birds represent only a mechanical transporter of oocysts (NAKAMURA et al., 2009; QUAH et al., 2011). However, even if birds are rarely infected by the Cryptosporidium species that are associated with mammals, aquatic birds mechanically transport the oocysts of zoonotic species, such as $C$. parvum and $C$. hominis, and may participate in the epidemiological chain of human cryptosporidiosis by means of environmental contamination (GRACZYK et al., 1998; ZHOU et al., 2004; GRACZYK et al., 2008; PLUTZER \& TOMOR, 2009).

\section{Concluding Remarks}

Among the three species and various genotypes of Cryptosporidium identified in birds, only partial information is available regarding their economic, clinical, pathological and epidemiological characteristics and their importance for public health. Most of this information concerns C. baileyi, C. galli, C. meleagridis, avian genotype II and avian genotype III. Birds are kept as pets, for ornamental purposes, in zoos, in wildlife conservation centers and for commercial poultry production. The importance of determining the various aspects of cryptosporidiosis as a zoonosis or as a disease with significance regarding the health of birds is undeniable.

Reports of clinical disease associated with the presence of Cryptosporidium spp. among birds are increasingly frequent. Cryptosporidiosis on commercial farms remains understudied, perhaps because it is a subclinical disease or because it presents clinical signs that are not pathognomonic. Moreover, cryptosporidiosis is not among the diseases that are routinely diagnosed in avian pathology laboratories.

Several aspects of avian cryptosporidiosis, particularly its pathogeny among domestic birds, were more frequently studied during the 1980s and 1990s. After this period, the focus of research on avian cryptosporidiosis was directed toward the detection and classification of species and genotypes of Cryptosporidium and their roles as zoonotic agents. New research related to natural or experimental infection by Cryptosporidium spp. among domestic and wild birds could elucidate factors that are still undefined, such as the importance of this parasite as a primary infection agent and its interaction with other etiological agents of infections in the gastrointestinal tract, respiratory tract and bursa of Fabricius.

\section{References}

Abbassi H, Coudert F, Dambrine G, Chérel Y, Naciri M. Effect of Cryptosporidium baileyi in specific pathogen free chickens vaccinated (CVI988/ Rispens) and challenged with HPRS-16 strain of Marek's. Avian Pathol 2000; 29(6): 623-634. http://dx.doi.org/10.1080/03079450020016887. PMid:19184860.

Abe N, Makino I. Multilocus genotypic analysis of Cryptosporidium isolates from cockatiels, Japan. Parasitol Res 2010; 106(6): 1491-1497. http://dx.doi.org/10.1007/s00436-010-1810-5. PMid:20339870.

Akiyoshi DE, Dilo J, Pearson C, Chapman S, Tumwine J, Tzipori S. Characterization of Cryptosporidium meleagridis of human origin passaged through different host species. Infect Immun 2003; 71(4): 1828-1832. http://dx.doi.org/10.1128/IAI.71.4.1828-1832.2003. PMid:12654797.

Allwright DM, Wessels J. Cryptosporidium species in ostriches. Vet Rec 1993 133(1): 24. http://dx.doi.org/10.1136/vr.133.1.24-a. PMid:8362489.

Antunes RG, Simóes DC, Nakamura AA, Meireles MV. Natural infection with Cryptosporidium galli in canaries (Serinus canaria), in a cockatiel (Nymphicus hollandicus), and in lesser seed-finches (Oryzoborus angolensis) from Brazil. Avian Dis 2008; 52(4): 702-705. http://dx.doi. org/10.1637/8356-051208-Case.1. PMid:19166068.

Baines D, Newborn D, Richardson M. Spread of Cryptosporidium baileyi in red grouse Lagopus lagopus scoticus. Vet Rec 2014; 175(6): 149. http:// dx.doi.org/10.1136/vr.102275. PMid:24934399.

Bamaiyi PH, Umoh JU, Abdu PA, Lawal IA. The prevalence of Cryptosporidium oocysts in Zaria, Nigeria. Borneo J Resour Sci Tech 2013; 2(2): 52-59.

Baroudi D, Khelef D, Goucem R, Adjou KT, Adamu H, Zhang H, et al. Common occurrence of zoonotic pathogen Cryptosporidium meleagridis in broiler chickens and turkeys in Algeria. Vet Parasitol 2013; 196(3-4): 334340. http://dx.doi.org/10.1016/j.vetpar.2013.02.022. PMid:23498647.

Barta JR, Thompson RC. What is Cryptosporidium? Reappraising its biology and phylogenetic affinities. Trends Parasitol 2006; 22(10): 463 468. http://dx.doi.org/10.1016/j.pt.2006.08.001. PMid:16904941.

Belton DJ, Powell IB. Cryptosporidiosis in lovebirds (Agapornis sp.). $N$ $Z$ Vet J 1987; 35(1-2): 15. http://dx.doi.org/10.1080/00480169.1987. 35364. PMid:16031325.

Bermudez AJ, Ley DH, Levy MG, Ficken MD, Guy JS, Gerig TM. Intestinal and bursal cryptosporidiosis in turkeys following inoculation with Cryptosporidium sp. isolated from commercial poults. Avian Dis 1988 32(3): 445-450. http://dx.doi.org/10.2307/1590910. PMid:3196261.

Bezuidenhout AJ, Penrith ML, Burger WP. Prolapse of the phallus and cloaca in the ostrich (Struthio camelus). J S Afr Vet Assoc 1993; 64(4): 156-158. PMid:8176694.

Blagburn BL, Lindsay DS, Giambrone JJ, Sundermann CA, Hoerr FJ. Experimental cryptosporidiosis in broiler chickens. Poult Sci 1987; 66(3): 442-449. http://dx.doi.org/10.3382/ps.0660442. PMid:3601855.

Blagburn BL, Lindsay DS, Hoerr FJ, Atlas AL, Toivio-Kinnucan M. Cryptosporidium sp. infection in the proventriculus of an Australian diamond firetail finch (Staganoplura bella: Passeriformes, Estrildidae). 
Avian Dis 1990; 34(4): 1027-1030. http://dx.doi.org/10.2307/1591401. PMid:2282009.

Blagburn BL, Lindsay DS, Hoerr FJ, Davis JF, Giambrone JJ. Pathobiology of cryptosporidiosis (C. baileyi) in broiler chickens. J Protozool 1991; 38(6): 25S-28S. PMid:1667932.

Bougiouklis PA, Weissenböck H, Wells A, Miller WA, Palmieri C, Shivaprasad HL. Otitis media associated with Cryptosporidium baileyi in a Saker falcon (Falco cherrug). J Comp Pathol 2013; 148(4): 419-423. http://dx.doi.org/10.1016/j.jcpa.2012.09.005. PMid:23123131.

Bowman DD, Lucio-Forster A. Cryptosporidiosis and giardiasis in dogs and cats: veterinary and public health importance. Exp Parasitol 2010; 124(1): 121-127. http://dx.doi.org/10.1016/j.exppara.2009.01.003. PMid:19545532.

Cardozo SV, Teixeira WL Fo, Lopes CWG. Avaliação das técnicas de rotina no diagnóstico de oocistos de Cryptosporidium baileyi em amostras de fezes de frangos de corte (Gallus gallus domesticus). Rev Bras Parasitol Vet 2008;17(S1 Suppl 1): 351-353. PMid:20059878.

Cardozo SV, Teixeira WL Fo, Lopes CWG. Transmissão experimental de Cryptosporidium baileyi (Apicomplexa: cryptosporidiidae) isolado de frango de corte à codorna Japonesa (Coturnix japonica). Rev Bras Parasitol Vet 2005; 14(3): 119-124. PMid:16229756.

Casemore DP. Laboratory methods for diagnosing cryptosporidiosis. J Clin Pathol 1991; 44(6): 445-451. http://dx.doi.org/10.1136/jcp.44.6.445. PMid:1712367.

Cavalier-Smith T. Gregarine site-heterogeneous $18 \mathrm{~S}$ rDNA trees, revision of gregarine higher classification, and the evolutionary diversification of Sporozoa. Eur J Protistol 2014; 50(5): 472-495. http://dx.doi.org/10.1016/j. ejop.2014.07.002. PMid:25238406.

Chalmers RM, Campbell BM, Crouch N, Charlett A, Davies AP. Comparison of diagnostic sensitivity and specificity of seven Cryptosporidium assays used in the UK. J Med Microbiol 2011; 60(Pt 11): 1598-1604. http:// dx.doi.org/10.1099/jmm.0.034181-0. PMid:21757501.

Chalmers RM, Giles M. Zoonotic cryptosporidiosis in the UK - challenges for control. J Appl Microbiol 2010; 109(5): 1487-1497. http://dx.doi. org/10.1111/j.1365-2672.2010.04764.x. PMid:20497274.

Chalmers RM, Katzer F. Looking for Cryptosporidium: the application of advances in detection and diagnosis. Trends Parasitol 2013; 29(5): 237-251. http://dx.doi.org/10.1016/j.pt.2013.03.001. PMid:23566713.

Chvala S, Fragner K, Hackl R, Hess M, Weissenböck H. Cryptosporidium infection in domestic geese (Anser anserf. domestica) detected by in-situ hybridization. J Comp Pathol 2006; 134(2-3): 211-218. http://dx.doi. org/10.1016/j.jcpa.2005.11.002. PMid:16615936.

Clubb S. What is your diagnosis? J Avian Med Surg 1997; 11(1): 41-42.

Coldwell L, Caldow G, Holliman A, Mearns R, Errington H, Giles $\mathrm{M}$, et al. Cryptospordium baileyi in wild red grouse with 'bulgy eye'. Vet Rec 2012; 170(23): 603-604. http://dx.doi.org/10.1136/vr.e3940. PMid:22696475.

Current WL, Upton SJ, Haynes TB. The life cycle of Cryptosporidium baileyi n. sp. (Apicomplexa, Cryptosporidiidae) infecting chickens. J Protozool 1986; 33(2): 289-296. http://dx.doi.org/10.1111/j.1550-7408.1986. tb05608.x. PMid:3735157.

Darabus G, Olariu R. The homologous and interspecies transmission of Cryptosporidium parvum and Cryptosporidium meleagridis. Pol J Vet Sci 2003; 6(3): 225-228. PMid:14510055.
Darabus G. Experimental studies of inter-and intraspecific transmission of Cryptosporidium parvum and C. meleagridis. Rev Rom Med Vet 1997; 7: 155-160.

Dhillon AS, Thacker HL, Dietzel AV, Winterfield RW. Respiratory cryptosporidiosis in broiler chickens. Avian Dis 1981; 25(3): 747-751. http://dx.doi.org/10.2307/1590007. PMid:7316908.

Eladl AH, Hamed HR, Khalil MR. Consequence of Cryptosporidiosis on the immune response of vaccinated broiler chickens against Newcastle disease and/or avian influenza. Vet Res Commun 2014; 38(3): 237-247. http://dx.doi.org/10.1007/s11259-014-9610-5. PMid:24993748.

Elliot A, Morgan UM, Thompson RCA. Improved staining method for detecting Cryptosporidium oocysts in stools using malachite green. $J$ Gen Appl Microbiol 1999; 45(3): 139-142. http://dx.doi.org/10.2323/ jgam.45.139. PMid:12501386.

Elwin K, Hadfield SJ, Robinson G, Chalmers RM. The epidemiology of sporadic human infections with unusual cryptosporidia detected during routine typing in England and Wales, 2000-2008. Epidemiol Infect 2012; 140(4): 673-683. http://dx.doi.org/10.1017/S0950268811000860. PMid:21733255.

Fayer R. General biology. In: Fayer R, Xiao L, editors. Cryptosporidium and Cryptosporidiosis. Boca Raton: CRC; 2008. p. 1-42.

Fayer R. Taxonomy and species delimitation in Cryptosporidium. Exp Parasitol 2010; 124(1): 90-97. http://dx.doi.org/10.1016/j.exppara.2009.03.005. PMid:19303009.

Fletcher OJ, Munnell JF, Page RK. Cryptosporidiosis of the bursa of Fabricius of chickens. Avian Dis 1975; 19(3): 630-639. http://dx.doi. org/10.2307/1589092. PMid:1164328.

Gharagozlou MJ, Dezfoulian O, Rahbari S, Bokaie S, Jahanzad I, Razavi ANE. Intestinal cryptosporidiosis in turkeys in Iran. J Vet Med A Physiol Pathol Clin Med 2006; 53(6): 282-285. http://dx.doi.org/10.1111/j.14390442.2006.00843.x. PMid:16901269.

Glisson JR, Brown TP, Brugh M, Page RK, Kleven SH, Davis RB. Sinusitis in turkeys associated with respiratory cryptosporidiosis. Avian Dis 1984; 28(3): 783-790. http://dx.doi.org/10.2307/1590250. PMid:6487198.

Gomes RS, Huber F, da Silva S, do Bomfim TC. Cryptosporidium spp. parasitize exotic birds that are commercialized in markets, commercial aviaries, and pet shops. Parasitol Res 2012; 110(4): 1363-1370. http:// dx.doi.org/10.1007/s00436-011-2636-5. PMid:21922240.

Goodwin MA, Brown J, Resurreccion RS, Smith JA. Respiratory coccidiosis (Cryptosporidium baileyi) among northern Georgia broilers in one company. Avian Dis 1996; 40(3): 572-575. http://dx.doi.org/10.2307/1592266. PMid:8883786.

Goodwin MA, Brown J. Intestinal cryptosporidiosis in chickens. Avian Dis 1989; 33(4): 770-777. http://dx.doi.org/10.2307/1591159. PMid:2619667.

Goodwin MA, Krabill VA. Diarrhea associated with small-intestinal cryptosporidiosis in a budgerigar and in a cockatiel. Avian Dis 1989; 33(4): 829-833. http://dx.doi.org/10.2307/1591170. PMid:2619673.

Goodwin MA, Steffens WL, Russell ID, Brown J. Diarrhea associated with intestinal Cryptosporidiosis in turkeys. Avian Dis 1988; 32(1): 6367. http://dx.doi.org/10.2307/1590949. PMid:3382381.

Goodwin MA. Cryptosporidiosis in birds-a review. Avian Pathol 1989; 18(3): 365-384. http://dx.doi.org/10.1080/03079458908418612. PMid:18679870. 
Goodwin MA. Small-intestinal cryptosporidiosis in a chicken. Avian Dis 1988; 32(4): 844-848. http://dx.doi.org/10.2307/1591011. PMid:3202780.

Gorham SL, Mallinson ET, Synder DB, Odor EM. Cryptosporidia in the bursa of Fabricius-a correlation with mortality rates in broiler chickens. Avian Pathol 1987; 16(2): 205-211. http://dx.doi. org/10.1080/03079458708436369. PMid:18766608.

Graczyk TK, Cranfield MR, Fayer R. Evaluation of commercial enzyme immunoassay (EIA) and immunofluorescent antibody (FA) test kits for detection of Cryptosporidium oocysts of species other than Cryptosporidium parvum. Am J Trop Med Hyg 1996; 54(3): 274-279. PMid:8600765.

Graczyk TK, Fayer R, Trout JM, Lewis EJ, Farley CA, Sulaiman I, et al. Giardia sp. cysts and infectious Cryptosporidium parvum oocysts in the feces of migratory Canada geese (Branta canadensis). Appl Environ Microbiol 1998; 64(7): 2736-2738. PMid:9647860.

Graczyk TK, Majewska AC, Schwab KJ. The role of birds in dissemination of human waterborne enteropathogens. Trends Parasitol 2008; 24(2): 55-59. http://dx.doi.org/10.1016/j.pt.2007.10.007. PMid:18165154.

Guy JS, Levy MG, Ley DH, Barnes HJ, Gerig TM. Experimental reproduction of enteritis in bobwhite quail (Colinus virginianus) with Cryptosporidium and reovirus. Avian Dis 1987; 31(4): 713-722. http:// dx.doi.org/10.2307/1591021. PMid:2831866.

Guy JS, Levy MG, Ley DH, Barnes HJ, Gerig TM. Interaction of reovirus and Cryptosporidium baileyi in experimentally infected chickens. Avian Dis 1988; 32(3): 381-390. http://dx.doi.org/10.2307/1590901. PMid:2848481.

Hao YX, Yang JM, He C, Liu Q, McAllister TA. Reduced serologic response to avian influenza vaccine in specific-pathogen-free chicks inoculated with Cryptosporidium baileyi. Avian Dis 2008; 52(4): 690693. http://dx.doi.org/10.1637/8370-052608-Reg.1. PMid:19166065.

Henriksen SA, Pohlenz JFL. Staining of cryptosporidia by a modified Ziehl-Neelsen technique. Acta Vet Scand 1981; 22(3-4): 594-596. PMid:6178277.

Hoerr FJ, Current WL, Haynes TB. Fatal cryptosporidiosis in quail. Avian Dis 1986; 30(2): 421-425. http://dx.doi.org/10.2307/1590550. PMid:3729889.

Hornok S, Heijmans JF, Békési L, Peek HW, Dobos-Kovács M, Drén $\mathrm{CN}$, et al. Interaction of chicken anaemia virus and Cryptosporidium baileyi in experimentally infected chickens. Vet Parasitol 1998; 76(1-2): 43-55. http://dx.doi.org/10.1016/S0304-4017(97)00046-0. PMid:9653989.

Huber F, da Silva S, Bomfim TCB, Teixeira KRS, Bello AR. Genotypic characterization and phylogenetic analysis of Cryptosporidium sp. from domestic animals in Brazil. Vet Parasitol 2007; 150(1-2): 65-74. http:// dx.doi.org/10.1016/j.vetpar.2007.08.018. PMid:17905514.

Insulander M, Silverlås C, Lebbad M, Karlsson L, Mattsson JG, Svenungsson B. Molecular epidemiology and clinical manifestations of human cryptosporidiosis in Sweden. Epidemiol Infect 2013; 141(5): 10091020. http://dx.doi.org/10.1017/S0950268812001665. PMid:22877562.

Itakura C, Goryo M, Umemura T. Cryptosporidial infection in chickens. Avian Pathol 1984; 13(3): 487-499. http://dx.doi.org/10.1080/03079458408418550. PMid:18766863.

Jardine JE, Verwoerd DJ. Pancreatic cryptosporidiosis in ostriches. Avian Pathol 1997; 26(3): 665-670. http://dx.doi.org/10.1080/03079459708419243. PMid:18483936.

Jellison KL, Distel DL, Hemond HF, Schauer DB. Phylogenetic analysis of the hypervariable region of the $18 \mathrm{~S}$ rRNA gene of Cryptosporidium oocysts in feces of Canada geese (Branta canadensis): evidence for five novel genotypes. Appl Environ Microbiol 2004; 70(1): 452-458. http:// dx.doi.org/10.1128/AEM.70.1.452-458.2004. PMid:14711674.

Jex AR, Smith HV, Monis PT, Campbell BE, Gasser RB. Cryptosporidium - biotechnological advances in the detection, diagnosis and analysis of genetic variation. Biotechnol Adv 2008; 26(4): 304-317. http://dx.doi. org/10.1016/j.biotechadv.2008.02.003. PMid:18430539.

Kik MJL, van Asten AJAM, Lenstra JA, Kirpensteijn J. Cloaca prolapse and cystitis in green iguana (Iguana iguana) caused by a novel Cryptosporidium species. Vet Parasitol 2011; 175(1-2): 165-167. http://dx.doi.org/10.1016/j. vetpar.2010.10.002. PMid:21036480.

Latimer KS, Goodwin MA, Davis MK. Rapid cytologic diagnosis of respiratory cryptosporidiosis in chickens. Avian Dis 1988; 32(4): 826830. http://dx.doi.org/10.2307/1591006. PMid:2462413.

Levy MG, Ley DH, Barnes HJ, Gerig TM, Corbett WT. Experimental cryptosporidiosis and infectious bursal disease virus infection of specificpathogen-free chickens. Avian Dis 1988; 32(4): 803-811. http://dx.doi. org/10.2307/1591002. PMid:2849406.

Ley DH, Moresco A, Frasca S Jr. Conjunctivitis, rhinitis, and sinusitis in cliff swallows (Petrochelidon pyrrhonota) found in association with Mycoplasma sturni infection and cryptosporidiosis. Avian Pathol 2012; 41(4): 395-401. http://dx.doi.org/10.1080/03079457.2012.697624. PMid:22834555.

Li J, Lin X, Zhang L, Qi N, Liao S, Lv M, et al. Molecular characterization of Cryptosporidium spp. in domestic pigeons (Columba livia domestica) in Guangdong Province, Southern China. Parasitol Res 2015; 114(6): 2237 2241. http://dx.doi.org/10.1007/s00436-015-4415-1. PMid:25773186.

Li N, Xiao L, Wang L, Zhao S, Zhao X, Duan L, et al. Molecular surveillance of Cryptosporidium spp., Giardia duodenalis, and Enterocytozoon bieneusi by genotyping and subtyping parasites in wastewater. PLoS Negl Trop Dis 2012; 6(9): e1809.

Lindsay DS, Blagburn BL, Ernest JA. Experimental Cryptosporidium parvum infections in chickens. J Parasitol 1987a; 73(1): 242-244. http:// dx.doi.org/10.2307/3282381. PMid:3572661.

Lindsay DS, Blagburn BL, Hoerr FJ. Small intestinal cryptosporidiosis in cockatiels associated with Cryptosporidium baileyi-like oocysts. Avian Dis 1990; 34(3): 791-793. http://dx.doi.org/10.2307/1591283. PMid:2241709.

Lindsay DS, Blagburn BL, Sundermann CA, Ernest JA. Chemoprophylaxis of cryptosporidiosis in chickens, using halofuginone, salinomycin, lasalocid, or monensin. Am J Vet Res 1987b; 48(3): 354-355. PMid:3565889.

Lindsay DS, Blagburn BL, Sundermann CA. Morphometric comparison of the oocysts of Cryptosporidium meleagridis and Cryptosporidium baileyi from birds. Proc Helminthol Soc Wash 1989; 56(1): 91-92.

Máca O, Pavlásek I. First finding of spontaneous infections with Cryptosporidium baileyi and C. meleagridis in the red-legged partridge Alectoris rufa from an aviary in the Czech Republic. Vet Parasitol 2015 209(3-4): 164-168. http://dx.doi.org/10.1016/j.vetpar.2015.03.003. PMid:25814162.

Makino I, Abe N, Reavill DR. Cryptosporidium avian genotype III as a possible causative agent of chronic vomiting in peach-faced lovebirds (Agapornis roseicollis). Avian Dis 2010; 54(3): 1102-1107. http://dx.doi. org/10.1637/9227-123009-Case.1. PMid:20945797.

Mason RW, Hartley WJ. Respiratory cryptosporidiosis in a peacock chick. Avian Dis 1980; 24(3): 771-776. http://dx.doi.org/10.2307/1589814. PMid:7447841. 
Mason RW. Conjunctival cryptosporidiosis in a duck. Avian Dis 1986; 30(3): 598-600. http://dx.doi.org/10.2307/1590428. PMid:3767818.

McEvoy JM, Giddings CW. Cryptosporidium in commercially produced turkeys on-farm and postslaughter. Lett Appl Microbiol 2009; 48(3): 302-306. http://dx.doi.org/10.1111/j.1472-765X.2008.02516.x. PMid:19187504.

Meireles MV, Figueiredo PC. Isolamento e identificação do Cryptosporidium baileyi Current et al. 1986 (Apicomplexa:Cryptosporidiidae) em frangos de corte. Rev Bras Parasitol Vet 1992; 1(2): 125-130.

Meireles MV, Paulillo AC, Costa AJ, Moraes FR, Ávila FA, Silva GS. Correlação entre Toxoplasma gondii e Cryptosporidium baileyi em frangos de corte experimentalmente infectados. Rev Bras Parasitol Vet 1995; 4(2): $105-112$

Meireles MV, Paulillo AC, Silva GS, Costa AJ, Júnior LD, Machado RZ. Infecção experimental por Cryptosporidium baileyi em aves de corte: I - Aspectos clínicos, parasitológicos e zootécnicos. Rev Bras Parasitol Vet 1998a; 7(1): 11-14.

Meireles MV, Paulillo AC, Silva GS, Costa AJ, Luvizotto MCR, Júnior $\mathrm{LD}$, et al. Influência da infecçáo experimental com Cryptosporidium baileyi na resposta imune de frangos de corte vacinados contra a doença de Newcastle. Rev Bras Cienci Vet 1998b; 5(1): 15-19.

Meireles MV, Paulillo AC, Silva GS, Luvizotto MCR, Costa AJ, Andreatti RL Fo. Experimental infection with Cryptosporidium baileyi in broilers raised on floor-pens. Braz J Poult Sci 1999; 1(1): 37-42.

Meireles MV, Soares RM, Santos MM, Gennari SM. Biological studies and molecular characterization of a Cryptosporidium isolate from ostriches (Struthio camelus). J Parasitol 2006; 92(3): 623-626. http:// dx.doi.org/10.1645/0022-3395(2006)92[623:BSAMCO]2.0.CO;2. PMid: 16884009

Molina-Lopez RA, Ramis A, Martín-Vazquez S, Gómez-Couso H, AresMazas E, Cacciò SM, et al. Cryptosporidium baileyi infection associated with an outbreak of ocular and respiratory disease in otus owls (Otus scops) in a rehabilitation centre. Avian Pathol 2010; 39(3): 171-176. http:// dx.doi.org/10.1080/03079451003717589. PMid:20544422.

Morgan UM, Monis PT, Xiao L, Limor J, Sulaiman I, Raidal S, et al. Molecular and phylogenetic characterisation of Cryptosporidium from birds. Int J Parasitol 2001; 31(3): 289-296. http://dx.doi.org/10.1016/ S0020-7519(00)00164-8. PMid:11226456.

Morgan UM, Xiao L, Limor J, Gelis S, Raidal SR, Fayer R, et al. Cryptosporidium meleagridis in an Indian ring-necked parrot (Psittacula krameri). Aust Vet J2000; 78(3): 182-183. http://dx.doi.org/10.1111/j.1751-0813.2000. tb10589.x. PMid:10860158.

Murakami S, Miyama M, Ogawa A, Shimada J, Nakane T. Occurrence of conjunctivitis, sinusitis and upper region tracheitis in Japanese quail (Coturnix coturnix japonica), possibly caused by Mycoplasma gallisepticum accompanied by Cryptosporidium sp. infection. Avian Pathol 2002; 31(4): 363-370. http://dx.doi.org/10.1080/030794502201633. PMid:12396337.

Naciri M, Mazzella O, Coudert F. Interactions cryptosporidies-virus sauvage ou vaccinal de la maladie de Marek chez le poulet. Rec Méd Vét 1989; 165(4): 383-387.

Nakamura AA, Homem CG, Silva AMJ, Meireles MV. Diagnosis of gastric cryptosporidiosis in birds using a duplex real-time PCR assay. Vet Parasitol 2014; 205(1-2): 7-13. http://dx.doi.org/10.1016/j.vetpar.2014.07.033. PMid:25155280.

Nakamura AA, Simóes DC, Antunes RG, Silva DC, Meireles MV. Molecular characterization of Cryptosporidium spp. from fecal samples of birds kept in captivity in Brazil. Vet Parasitol 2009; 166(1-2): 47-51. http://dx.doi.org/10.1016/j.vetpar.2009.07.033. PMid:19683397.

Nakamura K, Abe F. Respiratory (especially pulmonary) and urinary infections of Cryptosporidium in layer chickens. Avian Pathol 1988; 17(3): 703-711. http://dx.doi.org/10.1080/03079458808436487. PMid:18766726.

$\mathrm{Ng} \mathrm{J}$, Pavlasek I, Ryan U. Identification of novel Cryptosporidium genotypes from avian hosts. Appl Environ Microbiol 2006; 72(12): 7548-7553. http://dx.doi.org/10.1128/AEM.01352-06. PMid:17028234.

Nguyen ST, Fukuda Y, Tada C, Huynh VV, Nguyen DT, Nakai Y. Prevalence and molecular characterization of Cryptosporidium in ostriches (Struthio camelus) on a farm in central Vietnam. Exp Parasitol 2013; 133(1): 8-11. http://dx.doi.org/10.1016/j.exppara.2012.10.010. PMid:23142549.

O’Donoghue PJ, Tham VL, de Saram WG, Paull KL, McDermott S. Cryptosporidium infections in birds and mammals and attempted crosstransmission studies. Vet Parasitol 1987; 26(1-2): 1-11. http://dx.doi. org/10.1016/0304-4017(87)90071-9. PMid:2964117.

Oliveira FCR, Ederli NB, Ederli BB, Albuquerque MC, Santos MD. [Occurrence of Cryptosporidium spp. oocysts (Apicomplexa, Cryptosporidiidae) in ostriches, Struthio camelus L., 1758 (Aves, Struthionidae) reared in North and Lowered Coastline regions of the state of Rio de Janeiro, Brazil]. Rev Bras Parasitol Vet 2008;17(1 Suppl 1): 322-325. PMid:20059869.

Ortolani EL. Standardization of the modified Ziehl-Neelsen technique to stain oocysts of Cryptosporidium. Rev Bras Parasitol Vet 2000; 9(1): 29-31.

Özkul IA, Aydin Y. Small-intestinal cryptosporidiosis in a young pigeon. Avian Pathol 1994; 23(2): 369-372. http://dx.doi.org/10.1080/03079459408419006. PMid:18671103.

Pagès-Manté A, Pagès-Bosch M, Majó-Masferrer N, Gómez-Couso H, Ares-Mazás E. An outbreak of disease associated with cryptosporidia on a red-legged partridge (Alectoris rufa) game farm. Avian Pathol 2007; 36(4): 275-278. http://dx.doi.org/10.1080/03079450701439389. PMid:17620172.

Palkovič L, Maroušek V. The pathogenicity of Cryptosporidium parvum Tyzzer, 1912 and C. baileyi Current, Upton et Haynes, 1986 for chickens. Folia Parasitol (Praha) 1989; 36(3): 209-217. PMid:2583611.

Pavlásek I. Cryptosporidia: Biology, diagnosis, host spectrum, specificity, and the environment. Remed Klinicka Mikrobiol 1999; 3: 290-301.

Penrith ML, Bezuidenhout AJ, Burger WP, Putterill JF. Evidence for cryptosporidial infection as a cause of prolapse of the phallus and cloaca in ostrich chicks (Struthio camelus). Onderstepoort J Vet Res 1994; 61(4): 283-289. PMid:7501359.

Penrith ML, Burger WPAA. A Cryptosporidium sp. in an ostrich.J S Afr Vet Assoc 1993; 64(2): 60-61. PMid:8410943.

Plutzer J, Tomor B. The role of aquatic birds in the environmental dissemination of human pathogenic Giardia duodenalis cysts and Cryptosporidium oocysts in Hungary. Parasitol Int 2009; 58(3): $227-$ 231. http://dx.doi.org/10.1016/j.parint.2009.05.004. PMid:19446039.

Proctor SJ, Kemp RL. Cryptosporidium anserinum sp. n. (Sporozoa) in a domestic goose Anser anser L., from Iowa. J Protozool 1974; 21(5): 664-666. http://dx.doi.org/10.1111/j.1550-7408.1974.tb03724.x. PMid:4217367.

Qi M, Huang L, Wang R, Xiao L, Xu L, Li J, et al. Natural infection of Cryptosporidium muris in ostriches (Struthio camelus). Vet Parasitol 2014; 205(3-4): 518-522. http://dx.doi.org/10.1016/j.vetpar.2014.06.035. PMid:25178556. 
Qi M, Wang R, Ning C, Li X, Zhang L, Jian F, et al. Cryptosporidium spp. in pet birds: genetic diversity and potential public health significance. Exp Parasitol 2011; 128(4): 336-340. http://dx.doi.org/10.1016/j. exppara.2011.04.003. PMid:21557938.

Quah JX, Ambu S, Lim YAL, Mahdy MAK, Mak JW. Molecular identification of Cryptosporidium parvum from avian hosts. Parasitology 2011; 138(5): 573-577. http://dx.doi.org/10.1017/S0031182010001691. PMid:21232175.

Radfar MH, Asl EN, Seghinsara HR, Dehaghi MM, Fathi S. Biodiversity and prevalence of parasites of domestic pigeons (Columba livia domestica) in a selected semiarid zone of South Khorasan, Iran. Trop Anim Health Prod 2012; 44(2): 225-229. http://dx.doi.org/10.1007/s11250-0110002-3. PMid:22081317.

Ramirez NE, Ward LA, Sreevatsan S. A review of the biology and epidemiology of cryptosporidiosis in humans and animals. Microbes Infect 2004; 6(8): 773-785. http://dx.doi.org/10.1016/j.micinf.2004.02.021. PMid:15207825.

Randall CJ. Conjunctivitis in pheasants associated with cryptosporidial infection. Vet Rec 1986; 118(8): 211. http://dx.doi.org/10.1136/ vr.118.8.211. PMid:3716166.

Ravich ML, Reavill DR, Hess L, Childress AL, Wellehan JFX Jr. Gastrointestinal cryptosporidiosis in captive psittacine birds in the United States: a case review. J Avian Med Surg 2014; 28(4): 297-303. http:// dx.doi.org/10.1647/1082-6742-28.4.297. PMid:25843467.

Reboredo-Fernández A, Ares-Mazás E, Cacciò SM, Gómez-Couso H. Occurrence of Giardia and Cryptosporidium in wild birds in Galicia (Northwest Spain). Parasitology 2015; 142(7): 917-925. http://dx.doi. org/10.1017/S0031182015000049. PMid:25669618.

Rhee JK, Kim HC, Lee SB, Yook SY. Immunosuppressive effect of Cryptosporidium baileyi infection on vaccination against Newcastle disease in chicks. Korean J Parasitol 1998a; 36(2): 121-125. http://dx.doi. org/10.3347/kjp.1998.36.2.121. PMid:9637829.

Rhee JK, Yang HJ, Yook SY, Kim HC. Immunosuppressive effect of Cryptosporidium baileyi infection on vaccination against avian infectious bronchitis in chicks. Korean J Parasitol 1998b; 36(3): 203-206. http:// dx.doi.org/10.3347/kjp.1998.36.3.203. PMid:9755592.

Rhee JK, Yang HJ, Kim HC. Verification of immunosuppression in chicks caused by Cryptosporidium baileyi infection using Brucella abortus strain 1119-3. Korean J Parasitol 1998c; 36(4): 281-284. http://dx.doi. org/10.3347/kjp.1998.36.4.281. PMid:9868895.

Richter D, Wiegand-Tripp G, Burkhardt E, Kaleta EF. Natural infections by Cryptosporidium sp. in farm-raised ducks and geese. Avian Pathol 1994; 23(2): 277-286. http://dx.doi.org/10.1080/03079459408418995. PMid:18671092.

Ritter GD, Ley DH, Levy M, Guy J, Barnes HJ. Intestinal cryptosporidiosis and reovirus isolation from bobwhite quail (Colinus virginianus) with enteritis. Avian Dis 1986; 30(3): 603-608. http://dx.doi.org/10.2307/1590430. PMid:3021104.

Rohela M, Lim YA, Jamaiah I, Khadijah PYY, Laang ST, Nazri MH, et al. Occurrence of Cryptosporidium oocysts in wrinkled hornbill and other birds in the Kuala Lumpur National Zoo. Southeast Asian J Trop Med Public Health 2005;36(S4 Suppl 4): 34-40. PMid:16438177.

Ryan U, Fayer R, Xiao L. Cryptosporidium species in humans and animals: current understanding and research needs. Parasitology 2014; 141(13): 1667-1685. http://dx.doi.org/10.1017/S0031182014001085. PMid:25111501.
Ryan U, Hijjawi N. New developments in Cryptosporidium research. Int J Parasitol 2015; 45(6): 367-373. http://dx.doi.org/10.1016/j. ijpara.2015.01.009. PMid:25769247.

Ryan U, Xiao L, Read C, Zhou L, Lal AA, Pavlásek I. Identification of novel Cryptosporidium genotypes from the Czech Republic. Appl Environ Microbiol2003b; 69(7): 4302-4307. http://dx.doi.org/10.1128/ AEM.69.7.4302-4307.2003. PMid:12839819.

Ryan U. Cryptosporidium in birds, fish and amphibians. Exp Parasitol 2010; 124(1): 113-120. http://dx.doi.org/10.1016/j.exppara.2009.02.002. PMid:19545515.

Ryan UM, Xiao L, Read C, Sulaiman IM, Monis P, Lal AA, et al. A redescription of Cryptosporidium galli Pavlasek, 1999 (Apicomplexa: Cryptosporidiidae) from birds. J Parasitol 2003a; 89(4): 809-813. http:// dx.doi.org/10.1645/GE-74RI. PMid:14533694.

Santín M. Clinical and subclinical infections with Cryptosporidium in animals. $N Z$ Vet J 2013; 61(1): 1-10. http://dx.doi.org/10.1080/0048 0169.2012.731681. PMid:23134088.

Santos MMAB, Peiró JR, Meireles MV. Cryptosporidium infection in ostriches (Struthio camelus) in Brazil: clinical, morphological and molecular studies. Braz J Poult Sci 2005; 7(2): 113-117.

Schulze C, Kämmerling J, Kutzer P, Engelhardt A, Richter B. Cryptosporidium baileyi - infection in Red-breasted Merganser (Mergus serrator) ducklings from a zoological garden. Berl Munch Tierarztl Wochenschr 2012; 125(910): 428-431. PMid:23045806.

Scott TR. Our current understanding of humoral immunity of poultry. Poult Sci 2004; 83(4): 574-579. http://dx.doi.org/10.1093/ps/83.4.574. PMid:15109054.

Sevá AP, Funada MR, Richtzenhain L, Guimarães MB, Souza SO, Allegretti L, et al. Genotyping of Cryptosporidium spp. from free-living wild birds from Brazil. Vet Parasitol 2011; 175(1-2): 27-32. http://dx.doi. org/10.1016/j.vetpar.2010.09.031. PMid:21035268.

Shahiduzzaman M, Daugschies A. Therapy and prevention of cryptosporidiosis in animals. Vet Parasitol 2012; 188(3-4): 203-214. http://dx.doi.org/10.1016/j.vetpar.2012.03.052. PMid:22521978.

Silva DC, Homem CG, Nakamura AA, Teixeira WF, Perri SH, Meireles MV. Physical, epidemiological, and molecular evaluation of infection by Cryptosporidium galli in Passeriformes. Parasitol Res 2010; 107(2): 271277. http://dx.doi.org/10.1007/s00436-010-1858-2. PMid:20407911.

Silverlås C, Mattsson JG, Insulander M, Lebbad M. Zoonotic transmission of Cryptosporidium meleagridis on an organic Swedish farm. Int J Parasitol 2012; 42(11): 963-967. http://dx.doi.org/10.1016/j.ijpara.2012.08.008. PMid:23022616.

Šlapeta J. Cryptosporidiosis and Cryptosporidium species in animals and humans: a thirty colour rainbow? Int J Parasitol 2013; 43(12-13): $957-$ 970. http://dx.doi.org/10.1016/j.ijpara.2013.07.005. PMid:23973380.

Slavin D. Cryptosporidium meleagridis (sp. nov.). J Comp Pathol 1955; 65(3): 262-266. http://dx.doi.org/10.1016/S0368-1742(55)80025-2. PMid:13242675.

Smith HV, Cacciò SM, Cook N, Nichols RAB, Tait A. Cryptosporidium and Giardia as foodborne zoonoses. Vet Parasitol 2007; 149(1-2): 2940. http://dx.doi.org/10.1016/j.vetpar.2007.07.015. PMid:17728067.

Smith HV, Corcoran GD. New drugs and treatment for cryptosporidiosis. Curr Opin Infect Dis 2004; 17(6): 557-564. http://dx.doi.org/10.1097/00001432200412000-00008. PMid:15640710. 
Snyder DB, Current WL, Russek-Cohen E, Gorham SL, Mallinson ET, Marquardt WW, et al. Serologic incidence of Cryptosporidium in Delmarva broiler flocks. Poult Sci 1988; 67(5): 730-735. http://dx.doi. org/10.3382/ps.0670730. PMid:3405949.

Sréter T, Kovács G, Silva AJ, Pieniazek NJ, Széll Z, Dobos-Kovács $\mathrm{M}$, et al. Morphologic, host specificity, and molecular characterization of a Hungarian Cryptosporidium meleagridis isolate. Appl Environ Microbiol 2000; 66(2): 735-738. http://dx.doi.org/10.1128/AEM.66.2.735738.2000. PMid:10653744

Sréter T, Varga I. Cryptosporidiosis in birds - a review. Vet Parasitol 2000; 87(4): 261-279. http://dx.doi.org/10.1016/S0304-4017(99)00178-8. PMid:10669097.

Stensvold CR, Beser J, Axén C, Lebbad M. High applicability of a novel method for gp60-based subtyping of Cryptosporidium meleagridis. J Clin Microbiol 2014; 52(7): 2311-2319. http://dx.doi.org/10.1128/ JCM.00598-14. PMid:24740082.

Striepen B. Parasitic infections: time to tackle cryptosporidiosis. Nature 2013; 503(7475): 189-191. http://dx.doi.org/10.1038/503189a. PMid:24236315.

Tarwid JN, Cawthorn RJ, Riddell C. Cryptosporidiosis in the respiratory tract of turkeys in Saskatchewan. Avian Dis 1985; 29(2): 528-532. http:// dx.doi.org/10.2307/1590516. PMid:4026742.

Teixeira WFP, Coelho WMD, Nunes CM, Meireles MV. Detection of Cryptosporidium parvum oocysts in calf fecal samples by direct immunofluorescence assay. Rev Bras Parasitol Vet 2011b; 20(4): 269-273. http://dx.doi.org/10.1590/S1984-29612011000400003. PMid:22166379.

Teixeira WFP, Coelho WMD, Soutello RVG, Oliveira FP, Homem CG, Nunes CM, et al. Diagnóstico de criptosporidiose em amostras fecais de bezerros por imunofluorescência direta e microscopia de contraste de fase. Cienc Rural 2011a; 41(6): 1057-1062. http://dx.doi.org/10.1590/ S0103-84782011005000077

Tham VL, Kniesberg S, Dixon BR. Cryptosporidiosis in quails. Avian Pathol 1982; 11(4): 619-626. http://dx.doi.org/10.1080/03079458208436138. PMid: 18770229 .

Tyzzer EE. Coccidiosis in gallinaceous birds. Am J Epidemiol 1929; 10(2): 269-383.

Valigurová A, Jirků M, Koudela B, Gelnar M, Modrý D, Šlapeta J. Cryptosporidia: epicellular parasites embraced by the host cell membrane. Int J Parasitol 2008; 38(8-9): 913-922. http://dx.doi.org/10.1016/j. ijpara.2007.11.003. PMid:18158154.

van Zeeland YRA, Schoemaker NJ, Kik MJL, van der Giessen JWB. Upper respiratory tract infection caused by Cryptosporidium baileyi in three mixed-bred falcons (Falco rusticolus x Falco cherrug). Avian Dis 2008; 52(2): 357-363. http://dx.doi.org/10.1637/8121-100207-Case.1. PMid:18646471.
Wages DP, Ficken MD. Cryptosporidiosis and turkey viral hepatitis in turkeys. Avian Dis 1989; 33(1): 191-194. http://dx.doi.org/10.2307/1591088. PMid:2930401.

Wang L, Xue X, Li J, Zhou Q, Yu Y, Du A. Cryptosporidiosis in broiler chickens in Zhejiang Province, China: molecular characterization of oocysts detected in fecal samples. Parasite 2014b; 21: 36. http://dx.doi. org/10.1051/parasite/2014035. PMid:25075975.

Wang R, Jian F, Sun Y, Hu Q, Zhu J, Wang F, et al. Large-scale survey of Cryptosporidium spp. in chickens and Pekin ducks (Anas platyrhynchos) in Henan, China: prevalence and molecular characterization. Avian Pathol 2010; 39(6): 447-451. http://dx.doi.org/10.1080/03079457.2010.51 8314. PMid:21154053.

Wang R, Qi M, Jingjing Z, Sun D, Ning C, Zhao J, et al. Prevalence of Cryptosporidium baileyi in ostriches (Struthio camelus) in Zhengzhou, China. Vet Parasitol2011; 175(1-2): 151-154. http://dx.doi.org/10.1016/j. vetpar.2010.10.005. PMid:21030152.

Wang R, Wang F, Zhao J, Qi M, Ning C, Zhang L, et al. Cryptosporidium spp. in quails (Coturnix coturnix japonica) in Henan, China: molecular characterization and public health significance. Vet Parasitol 2012; 187(3-4): 534-537. http://dx.doi.org/10.1016/j.vetpar.2012.02.002. PMid:22377447.

Wang Y, Yang W, Cama V, Wang L, Cabrera L, Ortega Y, et al. Population genetics of Cryptosporidium meleagridis in humans and birds: evidence for cross-species transmission. Int J Parasitol 2014a; 44(8): 515-521. http:// dx.doi.org/10.1016/j.ijpara.2014.03.003. PMid:24727090.

Woodmansee DB, Pavlásek I, Pohlenz JFL, Moon HW. Subclinical cryptosporidiosis of turkeys in Iowa. J Parasitol 1988; 74(5): 898-900. http://dx.doi.org/10.2307/3282279. PMid:3418465.

Xiao L, Fayer R, Ryan U, Upton SJ. Cryptosporidium taxonomy: recent advances and implications for public health. Clin Microbiol Rev 2004; 17(1): 72-97. http://dx.doi.org/10.1128/CMR.17.1.72-97.2004. PMid:14726456.

Xiao L, Fayer R. Molecular characterisation of species and genotypes of Cryptosporidium and Giardia and assessment of zoonotic transmission. Int J Parasitol 2008; 38(11): 1239-1255. http://dx.doi.org/10.1016/j. ijpara.2008.03.006. PMid:18479685.

Xiao L, Feng Y. Zoonotic cryptosporidiosis. FEMS Immunol Med Microbiol 2008; 52(3): 309-323. http://dx.doi.org/10.1111/j.1574695X.2008.00377.x. PMid:18205803.

Zhou L, Kassa H, Tischler ML, Xiao L. Host-adapted Cryptosporidium spp. in Canada geese (Branta canadensis). Appl Environ Microbiol 2004; 70(7): 4211-4215. http://dx.doi.org/10.1128/AEM.70.7.4211-4215.2004. PMid:15240303.

Zylan K, Bailey T, Smith HV, Silvanose C, Kinne J, Schuster RK, et al. An outbreak of cryptosporidiosis in a collection of Stone curlews (Burhinus oedicnemus) in Dubai. Avian Pathol 2008; 37(5): 521-526. http://dx.doi. org/10.1080/03079450802357019 PMid:18798028. 